\title{
Assessing Competition in U.S. Wireless Markets: Review of the FCC's Competition Reports
}

\author{
Gerald R. Faulhaber \\ University of Pennsylvania Wharton School of Business \\ Robert W. Halm \\ Oxford University; Manchester; Georgetown Center for Business and Public Policy \\ Hal J. Singer \\ Navigant Economics
}

Follow this and additional works at: https://www.repository.law.indiana.edu/fclj

Part of the Administrative Law Commons, Antitrust and Trade Regulation Commons, Communications Law Commons, and the Legislation Commons

\section{Recommended Citation}

Faulhaber, Gerald R.; Halm, Robert W.; and Singer, Hal J. (2012) "Assessing Competition in U.S. Wireless Markets: Review of the FCC's Competition Reports," Federal Communications Law Journal: Vol. 64 : Iss. 2 , Article 4.

Available at: https://www.repository.law.indiana.edu/fclj/vol64/iss2/4

This Article is brought to you for free and open access by the Law School Journals at Digital Repository @ Maurer Law. It has been accepted for inclusion in Federal Communications Law Journal by an authorized editor of Digital Repository @ Maurer Law. For more information, please contact rvaughan@indiana.edu.

\section{$\Psi$}

JEROME HALL LAW LIBRARY

INDIANA UNIVERSITY

Maurer School of Law
Bloomington 


\title{
Assessing Competition in U.S. Wireless Markets: Review of the FCC's Competition Reports
}

\author{
Gerald R. Faulhaber*
}

\author{
Robert W. Hahn**
}

Hal J. Singer***

I. INTRODUCTION. 320

II. Direct Measures of MARKet Power ARE PREFERABLE to

INFERENCES BASED ON MARKET SHARES .............................. 327

III. DiRECT EVIDENCE OF WIRELESS PRICING DOES Not SUGGEST

MARKET POWER 330

IV. DIRECT EVIDENCE OF ENTRY BY NEW SUPPLIERS DOES NOT

SUGGEST MARKET POWER

* Gerald R. Faulhaber is Professor Emeritus in the Business and Public Policy Department of the University of Pennsylvania Wharton School of Business and is a former chief economist of the FCC.

** Robert W. Hahn is Director of Economics at the Smith School of Enterprise and the Environment at Oxford University, a Professor of Economics at Manchester, and a senior fellow at the Georgetown Center for Business and Public Policy.

*** Hal J. Singer is a Managing Director and Principal at Navigant Economics, LLC.

The views in this paper solely reflect those of the authors and do not necessarily represent those of the institutions with which they are affiliated. The authors would like to thank AT\&T for supporting this research. The Authors would like to recognize Srikant Narasimhan and Anna Koyfman for their excellent research assistance. 
A. Clearwire …................................................................ 338

B. Leap Wireless (Cricket) ................................................... 339

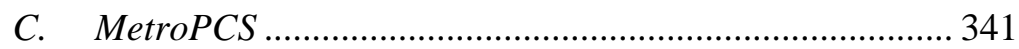

D. LightSquared................................................................. 344

E. Super Regional Carriers (U.S. Cellular, Cellular South, and Atlantic Tele-Network)............................................ 345

V. MARKeT StRUCTURE ANALYSIS PRESUMES A STRICT RELATIONSHIP BETWEEN PRICES AND NUMBER OF

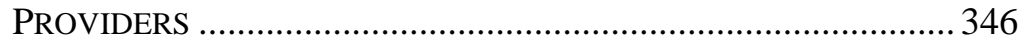

VI. VERIZON AND AT\&T DO NOT APPEAR TO POSSESS A "MUST-

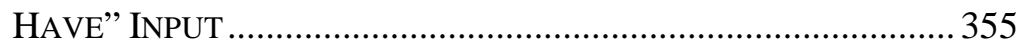

A. The Nextel Re-Banding Process ...................................... 356

B. Spectrum Is One of Several Inputs in the Production

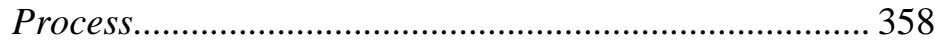

C. The Requisite Level of Spectrum Below-1000 MHz......... 358

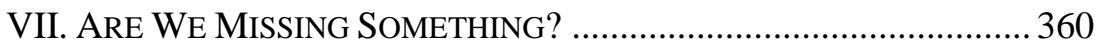

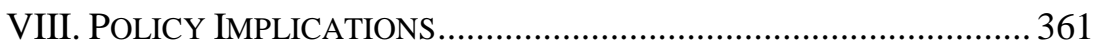

A. Handset Exclusivity....................................................... 361

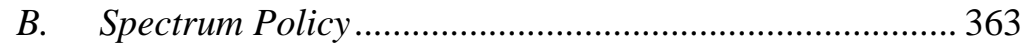

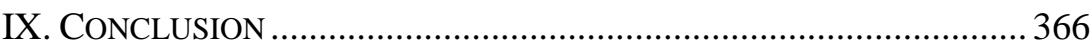

\section{INTRODUCTION}

Last year's Annual Report and Analysis of Competitive Market Conditions with Respect to Mobile Wireless ("14th Wireless Report"), issued by the FCC, broke new ground compared to prior reports. ${ }^{1}$ The FCC should be commended for its willingness to expand the scope of its competition report, for example, by including related markets such as handsets and applications as part of its analysis. ${ }^{2}$ The report also broke new ground by not concluding, as it had in prior reports, that the wireless services market was effectively competitive. ${ }^{3}$ This year's report (" 15 th Wireless Report") followed suit and refrained from making any

1. Annual Report and Analysis of Competitive Market Conditions with Respect to Mobile Wireless, Including Commercial Mobile Services, Fourteenth Report, 25 F.C.C.R. 11407 (May 20, 2010) [hereinafter 14th Wireless Report]. In addition to withdrawing its finding of effective competition, the FCC also changed the title of the report from "13th Annual CMRS Report" to "14th Mobile Wireless Competition Report." See Commercial Mobile Radio Services (CMRS) Competition Reports, FCC, http://www.fcc.gov/reports? filter_terms $[0]=0 \&$ filter_terms $[1]=96 \&$ topics $[0]=0 \& o p=A p p l y \% 20$ Filter http://wireless.fcc. gov/ index.htm?job=cmrs_reports (last visited Feb. 20, 2012).

2. 14th Wireless Report, supra note 1, at paras. 239-41.

3. 14th Wireless Report, supra note 1 , at para. 16. This term is generally used as a surrogate for "good performance." 
competitive assessment. ${ }^{4}$ This retreat from the FCC's earlier competitive assessments suggests a change in the FCC's outlook on this market. In addition, the omission of a statement on competition in this market appears to directly contravene Congress's mandate to the FCC to produce annually a Competition Report that "shall include in its annual report an analysis of . . whether or not there is effective competition.",5

A key issue in reaching a conclusion about effective competition is how to interpret the evidence. The 14th and 15th Wireless Reports review a wide variety of evidence, both direct (how firms and customers behave) and indirect (industry concentration measures). ${ }^{6}$ The reports are silent, however, on how to interpret this evidence. In contrast, modern antitrust analysis tends to rely far more on direct evidence and less on indirect evidence. Ironically, at least one highly influential reader $^{7}$ of the reports focuses entirely on the indirect (less relevant) evidence to draw a strongly negative assessment, which we think is unwarranted. We are concerned that this apparent refusal of the FCC to follow modern competitive analysis standards bodes ill for future regulatory decision making (in this as well as other markets).

In failing to put more weight on the relevant direct market evidence to reach a more informed competitive assessment, the 14th and 15th Wireless

4. Annual Report and Analysis of Competitive Market Conditions with Respect to Mobile Wireless, Including Commercial Mobile Services, Fifteenth Report, 26 F.C.C.R. 9664 (June 27, 2011) [hereinafter 15th Wireless Report].

5. 47 U.S.C. $\$ 332(c)(1)(C)(2010)$.

6. See 14th Wireless Report, supra note 1, at para. 48. See also 15th Wireless Report, supra note 4 , at para. 40.

7. In his statement relating to the 14th Wireless Report, Commissioner Copps was quite clear in his reliance on indirect evidence, noting that,

One number sticks out like a sore thumb: the Herfindahl-Hirschman Index-a widely-recognized and highly-credible measurement of industry concentration-shows that the concentration of mobile wireless service providers has skyrocketed to a weighted average of 2848. That's a jump of nearly 700 since we first calculated this metric a mere 7 years ago! So without denying those things that are right in the wireless world—and they are manythe facts also tell us that some things are not right.

14th Wireless Report, supra note 1, at 11703. Commissioner Copps again focused on the concentration data in the 15th Wireless Report:

Finally, I cannot ignore some of the darkening clouds over the state of mobile competition. The headline for this Report will be that the FCC neither finds nor does not find effective competition. Dig deeper and, sure enough, we find ongoing trends of industry consolidation. The well-accepted metric for market concentration, the Herfindahl-Hirschman Index, remains above the threshold for a 'highly concentrated' market.

15th Wireless Report, supra note 4, at 9968. See discussion infra Parts II, V (discussing overreliance on indirect measures of market power). 
Reports invite erroneous conclusions about the real state of competition in wireless markets. Stated differently, the FCC's purpose should be to directly assess performance. To be fair, in the introduction to its 15 th Wireless Report, the FCC acknowledges that "market performance metrics provide more direct evidence of competitive outcomes and the strength of competitive rivalry than market structure factors, such as concentration measures." structure-suggesting that market structure provides an important barometer of wireless competition-and its Herfindahl-Hirschman Index ("HHI") calculations are highlighted in the Executive Summary (which precedes the Introduction) without the appropriate disclaimer that concentration may not indicate market power. ' We are concerned that the FCC's undue emphasis on indirect evidence could eventually adversely influence regulatory policy in wireless markets. ${ }^{10}$

Economists generally believe that competitive analysis should be about satisfying customers. If firms exercise market power, customers may suffer through higher prices, reduced quality, and foreclosed entry of new competitors. If firms are not exercising market power, the market will have strong competition, customers will get what they want, and regulators do not need to intervene in the market. Traditionally, competitive analysis was not based on measuring what is happening to customers. Because economists did not have the tools to adequately measure this effect, they relied on indirect measures, such as market share in the relevant markets, the HHI, and market definitions. ${ }^{11}$

The approach to market analysis changed substantially with the landmark Staples-Office Depot proposed merger. The Federal Trade Commission ("FTC") employed a new standard of direct evidence, examining whether the merger would actually raise prices to customers instead of using indirect measures. It found compelling direct evidence that in markets without the presence of both firms, prices were significantly higher. ${ }^{12}$ Accordingly, the agency denied the merger. Since then, this direct

8. 15th Wireless Report, supra note 4, at para. 10.

9. Id. at 16 .

10. The FCC has excellent staff economists who are well equipped to perform a stateof-the-art competitive analysis. We are dismayed that the FCC failed to use the considerable staff talents at their disposal to draw the obvious conclusion, based on the direct evidence, that this market exhibits "effective competition."

11. See, e.g., Carl Shapiro, Mergers with Differentiated Products, 10 AnTITRUST 23 (Spring 2010).

12. See Press Release, Federal Trade Comm'n, Federal Trade Commission Rejects Proposed Settlement in Staples/Office Depot Merger (Apr. 4, 1997) (on file with the Federal Trade Commission) ("The FTC's decision to ask a court to block the merger is about lower prices for consumers. If the merger is allowed to proceed, consumers will pay millions of 
approach has become the modern standard for conducting competitive analysis.

To determine whether firms are exercising monopoly power, one looks directly at the conduct of the firm: Does the firm in question behave like a monopolist? This direct approach has been widely embraced by academic economists, ${ }^{13}$ and in 2010 , the federal antitrust agencies revised the Horizontal Merger Guidelines to reflect this new thinking in competition analysis. ${ }^{14}$ A review of the 14th and 15th Wireless Reports reveals that the FCC considered in great detail (but did not rely upon) this direct evidence of market power. ${ }^{15}$ For example, in Table 19 of the 14th Wireless Report, the FCC chronicles the downward trajectory of average revenue per voice minute from 1993 through 2008 (\$0.44 to \$0.05) and the upward trajectory of minutes of use per month over the same period (140 to $708),{ }^{16}$ but fails to attribute these massive consumer welfare gains to enhanced competition. ${ }^{17}$

dollars more for their copy paper, envelopes, pens and file folders.").

13. See, e.g., Aaron S. Edlin \& Daniel L. Rubinfeld, Exclusion or Efficient Pricing? The "Big Deal" Bundling of Academic Journals, 72 ANTITRUST L. J. 119, 141 (2004) ("Market definition is only a traditional means to the end of determining whether power over price exists. Power over price is what matters. As is stated in the Areeda, Elhauge, and Hovenkamp treatise, cases such as Microsoft, and the Areeda, Kaplow, and Edlin casebook, if power can be shown directly, there is no need for market definition: the value of market definition is in cases where power cannot be shown directly and must be inferred from sufficiently high market share in a relevant market.").

14. See U.S. Dep't of Just. and the Fed. Trade Comm'n, Horizontal Merger Guidelines (Aug. 2010) [hereinafter 2010 MERGER GuIDELINES]; see also discussion infra Part II.

15. Despite the obvious difference in competition analysis between the FCC and the antitrust agencies, the FCC remarkably claims that "DOJ's position on competition policy is in agreement with the approach taken in the Fourteenth Report." 14th Wireless Report, supra note 1 , at para. 16. In fact, the DOJ embraces a decidedly different perspective on competition analysis generally and on wireless competition in particular. See, Economic Issues in Broadband Competition, Ex Parte Submission of the United States Department of Justice, GN Docket No. 09-51, Sec. C.2 ("The history of competition in the mobile wireless market suggests that the entry of additional providers has resulted in consumers paying less, receiving new features and better handsets, and enjoying higher quality service. . . "As a result, consumers seem to be paying less on a per-minute basis for voice services and are using their mobile wireless devices more. The average wireless revenue per minute has declined from about 37 cents in 1997 to 6 cents in 2007, and average monthly minutes of use have increased from about 100 to almost 800 over the same period.").

16. 14th Wireless Report, supra note 1, at 11531 tbl.19. The report also notes the decline in prices for wireless handsets generally and smartphones in particular. Id. at 11592 chart 45 .

17. The report focuses instead on carrier profitability as a measure of market power. See id. at paras. 215-16. High profits could also come from superior performance, an alternative hypothesis not considered by the FCC. Indeed, the FCC cites high churn rates among wireless carriers, which corroborates the alternative, competition hypothesis. See id. para. 245 ("Most providers report churn rates for postpaid subscribers of between 1.5 
The Reports critically ignored the continuing downward trajectory in wireless prices. Despite its June 2011 release, the 15th Wireless Report tracks the Bureau of Labor Statistics' ("BLS") Cellular Consumer Price Index ("CPI") and industry average revenues per user ("ARPUs") only through 2009. ${ }^{18}$ According to the BLS, wireless prices decreased by 3 percent from January 2008 to December 2010. By comparison, the CPI for all goods and services increased by nearly 4 percent over the same period. ${ }^{19}$ Thus, by failing to extend its time series through December 2010 , the 15th Wireless Report missed an important price decline (of nearly 3 percent) from December 2009 through December 2010 and focused instead on the nearly constant prices from December 2008 through December 2009. Indeed, the same series shows wireless prices falling by another 3 percent from December 2010 through May 2011. Falling prices and market power usually do not coexist; this secular price decline is far more likely to signal effective competition, not market power.

The 14th and 15th Wireless Reports ignored this and similar direct evidence of competition-namely, aggressive pricing behavior, robust entry, and continued long-term reduction in prices, all of which strongly support a conclusion of "effective competition." 20 Instead, the FCC focuses on inferences of market power based on market shares. For example, in the 14th Wireless Report, the FCC makes much of the combined share of the top four wireless providers $^{21}$ generally, and of the top two wireless

percent and 3.3 percent per month (see Chart 38).”).

18. See 15th Wireless Report, supra note 4, at para 2.

19. See Bureau of Labor Statistics, CPI Detailed Report: Data for January 2008 34-40 tbl.3 (Malik Crawford ed., 2008), http://www.bls.gov/cpi/cpid0801.pdf. See also Bureau of Labor Statistics, CPI Detailed RePort: Data For December $201011-$ 17 tbl.3 (Malik Crawford et al. eds., 2010), http://www.bls.gov/cpi/cpid0801.pdf. According to the BLS, wireless prices decreased by 3 percent from January 2008 to December 2010 (from 64.089 in 2008 to 61.339 in 2010). By comparison, the CPI for all items increased by nearly 8 percent (from 211.512 in 2008 to 219.179 in 2010).

20. See 15th Wireless Report, supra note 4, at para. 2.

21. See 14th Wireless Report, supra note 1, at para. 30 (emphasis added) ("From these data, we see that the four nationwide service providers account for 90 percent of the nation's mobile wireless subscribers (including Mobile Virtual Network Operator (MVNO) subscribers), with AT\&T and Verizon Wireless accounting for 60 percent)."). Given that MVNOs offer different service plans (for example, pre-paid), they arguably should be considered distinct providers. However, the FCC's treatment of MVNO subscribers in its market share calculations suggests that MVNO customers are really not customers of the MVNO, but instead are customers of the underlying facilities-based provider. In seeking to diminish the role of MVNOs, the FCC later argues that "because MVNOs purchase their mobile wireless services in wholesale contracts from facilities-based providers, the ability of MVNOs to compete against their host facilities-based provider is limited." Id. at para. 32. Sears buys its appliances from General Electric and others, which Sears markets under the Kenmore name. To the extent that General Electric is competing with Kenmore/Sears, MVNOs are competing with facilities-based wireless carriers. 
providers, AT\&T and Verizon, in particular. ${ }^{22}$ Tellingly, the FCC admits that "[s]hares of subscribers and measures of concentration are not synonymous with market power-the ability to charge prices above the competitive level for a sustained period of time." ${ }^{23}$ The 15 th Wireless Report repeats this warning nearly verbatim. ${ }^{24}$ Despite the direct evidence of the lack of pricing power that the report presented, the FCC was unwilling to conclude, as it had in the prior six reports on this subject to Congress, that the U.S. wireless market was "effectively competitive." Although the FCC correlated HHI in a local geographic area with population densities in both reports, ${ }^{25}$ it failed to correlate HHI with wireless prices in either report. Had it done so, it would have discovered that as the nationwide average HHI increased from 2,151 in December 2003 to 2,848 in June 2010 (depicted on the first Y axis), and wireless prices as measured by the Cellular CPI were falling (depicted on the second Y axis).

22. Although the 14th Wireless Report often touts AT\&T and Verizon's combined share as being " 60 percent" of wireless subscribers, their combined shares are actually lower based on the FCC's own data. According to Chart 1 of the Report, the combined share of subscribers for AT\&T and Verizon was 54.8 percent. Id. at 11441 chart 1 . See also id. at 11621 tbl.41 (noting that Merrill Lynch estimates the combined share of AT\&T and Verizon to be 55.2 percent). At best, the FCC's 60 percent market share figure was arrived through rounding error.

23. Id. at para. 55 (emphasis added).

24. 15th Wireless Report, supra note 4, at para. 54 ("Shares of subscribers and measures of concentration are not synonymous with a non-competitive market or with market power - the ability to charge prices above the competitive level for a sustained period of time.").

25. See id. at para. 53 . 
Figure 1: Industry Concentration Is Rising While Cellular Prices Are Falling $^{26}$

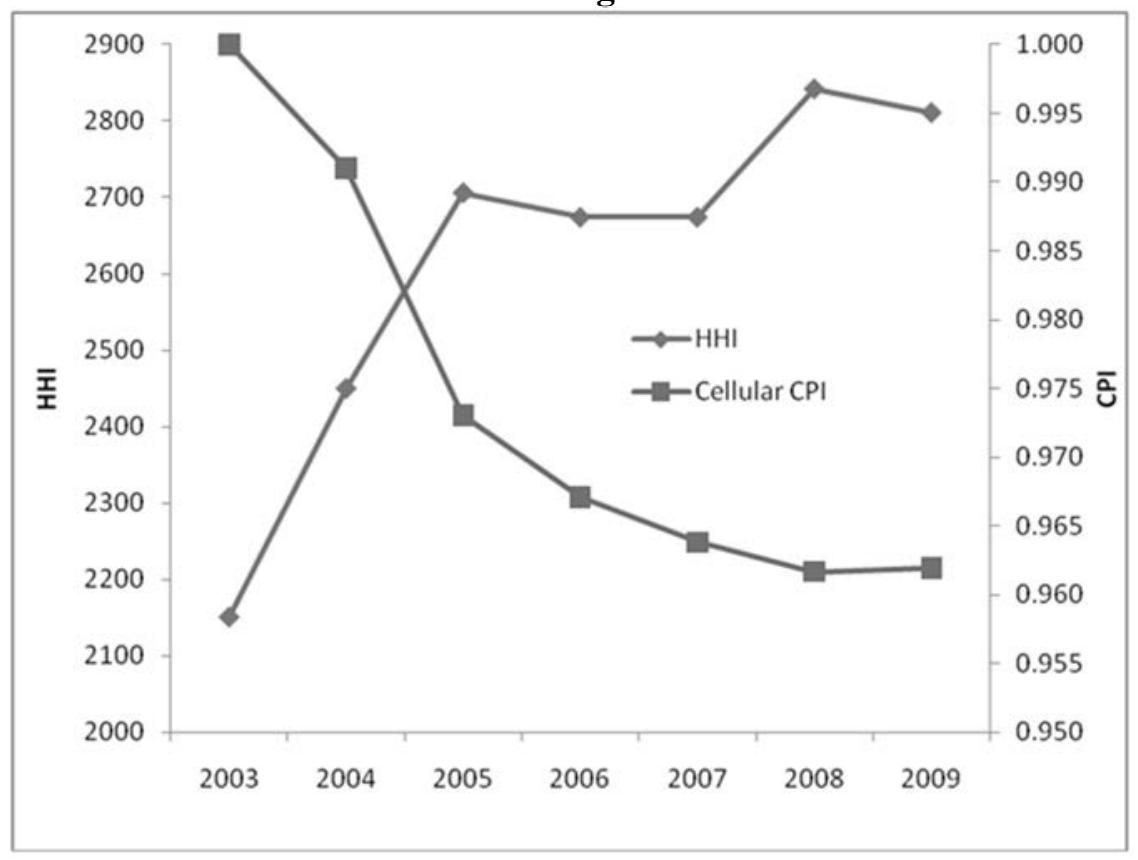

In this report, we suggest how the FCC can improve its competitive analysis for future mobile wireless competition reports to be more consistent with modern economic analysis. Part II explains how direct evidence of market power has supplanted inferences based on market shares of some relevant market. In Part III, we assess the direct evidence of pricing power (or lack thereof) in the wireless services industry. We examine the direct evidence of exclusion (or lack thereof), the other hallmark of non-competitive markets, in Part IV. Entry by Clearwire, Leap, MetroPCS, the cable television providers, and LightSquared is inconsistent with any claim of monopolization. In Part V, we explain that a market structure analysis presumes a relationship between prices and the number of providers, when such a relationship does not always exist. Part VI investigates whether Verizon or AT\&T possesses a "must-have" input that, if withheld from rivals, would impair their ability to compete effectively. In Part VII, we ask whether we are missing something critical to the competition analysis. Part VIII reviews the policy implications of our findings with respect to handset exclusivity and spectrum allocation.

26. Id. at 9710 tbl.9, 9782 tbl.19. Notes: Population-weighted average HHI of 172 Economic Areas as computed by the FCC. Cellular CPI is denominated in 2003 Prices. 


\section{Direct Measures of Market Power ARe Preferable to INFERENCES BASED ON MARKET SHARES}

As a general matter, direct evidence of monopoly power or anticompetitive effects is superior to indirect evidence of monopoly power derived from a traditional market definition inquiry (in which one defines a market to estimate market shares). The reason is that direct evidence, by definition, is based on actual market experience, whereas indirect evidence is not.

Indeed, due to the conceptual and practical issues associated with demonstrating market power indirectly, many antitrust scholars and economists have embraced the use of direct evidence of market power as opposed to strict adherence to industry concentration. ${ }^{27}$ This is not to say that indirect assessments of competition have no value; rather, the best approach may be to use indirect (but easily computed) evidence as a screen, which can be used to identify situations requiring deeper and more accurate analyses using direct evidence.

In fact, the federal antitrust agencies updated the Horizontal Merger Guidelines in 2010 to focus more on direct evidence when assessing horizontal competition issues-that is, issues that involve conduct among rivals in the same industry. The Horizontal Merger Guidelines relegate the use of market shares and industry concentration to a component of competition analysis. ${ }^{28}$ Instead, the Horizontal Merger Guidelines stress direct evidence of likely competitive effects, including (1) actual effects in consummated mergers (for example, analyses or documents indicating an imminent price increase by the parties post-merger); ${ }^{29}$ (2) making use of an

27. See, e.g., Jonathan B. Baker, Market Definition: An Analytical Overview, 74 ANTITRUST L. J. 129, 131 (2007) ("But market definition may not be required when market power or anticompetitive effect can be demonstrated directly through means other than inference from the number, size distribution, and other characteristics of firms.").

28. See 2010 MERGER Guidelines, supra note 14, $\$ 2.1 .3$ ("Mergers that cause a significant increase in concentration and result in highly concentrated markets are presumed to be likely to enhance market power, but this presumption can be rebutted by persuasive evidence showing that the merger is unlikely to enhance market power.").

29. See id. § 2.1.1 ("When evaluating a consummated merger, the ultimate issue is not only whether adverse competitive effects have already resulted from the merger, but also whether such effects are likely to arise in the future. Evidence of observed post-merger price increases or other changes adverse to customers is given substantial weight. The Agencies evaluate whether such changes are anticompetitive effects resulting from the merger, in which case they can be dispositive. However, a consummated merger may be anticompetitive even if such effects have not yet been observed, perhaps because the merged firm may be aware of the possibility of post-merger antitrust review and moderating its conduct. Consequently, the Agencies also consider the same types of evidence they consider when evaluating unconsummated mergers.”). 
existing natural experiment; ${ }^{30}$ (3) evidence of head-to-head competition between the parties; ${ }^{31}$ and (4) the disruptive role of a maverick firm. ${ }^{32}$

Excessive focus on industry concentration as a means to assess market power is an antiquated concept that presumes (sometimes incorrectly) a direct relationship between industry structure and pricesthat is, higher concentration is predicted to lead to higher prices. The widely held notion that greater concentration leads to greater market power was supported by early empirical research, which at the time indicated that industries with higher levels of concentration appeared to exhibit higher accounting profits than less concentrated industries. ${ }^{33}$ Even this earlier research resulted in a weak statistical correlation, and it could not be used to conclude that any specific industry abided by the structure-conduct hypothesis. In any event, later research has called these findings into question on both empirical and theoretical grounds. ${ }^{34}$ As noted by

30. See id. $\S 2.1 .2$ ("The Agencies look for historical events, or 'natural experiments,' that are informative regarding the competitive effects of the merger. For example, the Agencies may examine the impact of recent mergers, entry, expansion, or exit in the relevant market. Effects of analogous events in similar markets may also be informative. The Agencies also look for reliable evidence based on variations among similar markets. For example, if the merging firms compete in some locales but not others, comparisons of prices charged in regions where they do and do not compete may be informative regarding post-merger prices. In some cases, however, prices are set on such a broad geographic basis that such comparisons are not informative. The Agencies also may examine how prices in similar markets vary with the number of significant competitors in those markets.").

31. See id. $\S 2.1 .4$ ("The Agencies consider whether the merging firms have been, or likely will become absent the merger, substantial head-to-head competitors. Such evidence can be especially relevant for evaluating adverse unilateral effects, which result directly from the loss of that competition.").

32. See id. $\S 2.1 .5$ ("The Agencies consider whether a merger may lessen competition by eliminating a 'maverick' firm, i.e., a firm that plays a disruptive role in the market to the benefit of customers. For example, if one of the merging firms has a strong incumbency position and the other merging firm threatens to disrupt market conditions with a new technology or business model, their merger can involve the loss of actual or potential competition. Likewise, one of the merging firms may have the incentive to take the lead in price cutting or other competitive conduct or to resist increases in industry prices. A firm that may discipline prices based on its ability and incentive to expand production rapidly using available capacity also can be a maverick, as can a firm that has often resisted otherwise prevailing industry norms to cooperate on price setting or other terms of competition.").

33. Joe S. Bain, Relation of Profit Rate to Industry Concentration: American Manufacturing, 1936-1940, 65 Q. J. ECON. 293 (1951); Harold Demsetz, Two Systems of Belief About Monopoly, in EfFiciency, Competition, AND Policy 96 (1989) ("By 1960, then, collected evidence indicated a weak but generally positive correlation between concentration and profit rates.").

34. See, e.g., Timothy J. Muris, Improving the Economic Foundations of Competition Policy, 12 GEO. MASON L. REv. 1, 10 (2003) ("The SCP paradigm was overturned because its empirical support evaporated."); Timothy J. Muris, Economics and Antitrust, 5 GeO. Mason L. Rev. 303, 306 (1997) [hereinafter Economics and Antitrust] ("Although a 
Professor Robert Willig, former deputy assistant attorney general of the DOJ's Antitrust Division, "[a]ny reliance on such [concentration] metrics in the wireless industry, given its dynamic nature and complexity, likely will lead to misguided, and perhaps counterproductive, regulatory decisions." ${ }^{, 35}$ Market concentration is no longer the primary focus of competition analysis but just one of many factors that assess the extent of market power.

A far more appropriate way to assess pricing power is to look at direct evidence such as the trajectory of prices, price-cost relationships, and demand responses to price increases ("price effects"). Many courts have applied this direct evidence standard to decisions in antitrust ligation and acknowledged the validity of this approach. ${ }^{36}$ The types of informative direct evidence turn on the definition of market power. Economists typically agree that market power should be defined as (1) the ability to set prices above competitive levels ${ }^{37}$ and (2) the ability to exclude rivals. ${ }^{38}$

majority of antitrust economists and legal scholars prior to [the early 1970s] almost certainly believed that concentration was a major problem, that consensus collapsed."). Increased concentration will be observed if some firms are simply more efficient than others, meaning that profits cause concentration, not vice-versa. See Demsetz, supra note 33, at 103-04; F. M. Scherer, Industrial Market Structure And Economic Performance 280 (2d ed. 1980) ("Up to this point it has been assumed that the higher average profitability observed for concentrated industries comes from the power to elevate prices that monopoly confers. There is, however, an alternative hypothesis: that the relationships reflect the superior efficiency of large oligopolistic sellers.").

35. Comments of AT\&T Inc., Declaration of Robert D. Willig at 10-11, Implementation of Section 6002(b) of the Omnibus Budget Reconciliation Act of 1993, WT Docket No. 09-66 (Sept. 30, 2009).

36. See, e.g., Broadcom Corp. v. Qualcomm Inc., 501 F.3d 297, 307 (3d Cir. 2007) ("The existence of monopoly power may be proven through direct evidence of supracompetitive prices and restricted output.”); PepsiCo, Inc. v. Coca-Cola Co., 315 F.3d 101, 107 (2d Cir. 2002) (per curiam) (holding that "there is authority to support [the proposition] that a relevant market definition is not a necessary component of a monopolization claim.”); United States v. Microsoft Corp., 253 F.3d 34, 51 (D.C. Cir. 2001) (stating that if "evidence indicates that a firm has in fact [profitably raised prices substantially above the competitive level] the existence of monopoly power is clear."); Toys "R" Us v. FTC, 221 F.3d 928, 937 (7th Cir. 2000) (using defendant's ability to restrict output and, thereby, raise prices as proof of market power); Re/Max Int'l, Inc. v. Realty One, Inc., 173 F.3d 995, 1016 (6th Cir. 1999) ("[A]lthough the Plaintiffs failed to define the relevant market with precision and therefore failed to establish the defendants' monopoly power through circumstantial evidence, there does exist a genuine issue of material fact as to whether the Plaintiffs' evidence shows direct evidence of a monopoly, that is, actual control over prices or actual exclusion of competitors."); Rebel Oil Co., v. Atlantic Richfield Co., 51 F.3d 1421, 1434 (9th Cir. 1995) ("If the plaintiff puts forth evidence of restricted output and supracompetitive prices, that is direct proof of the injury to competition which a competitor with market power may inflict, and thus, of the actual exercise of market power.").

37. See, e.g., Edlin \& Rubinfeld, supra note 13, at 141 ("Market definition is only a traditional means to the end of determining whether power over price exists. Power over 
In sum, the 14th and 15th Wireless Reports focus excessive attention on outdated measures of competition and do not appear to put much weight on direct evidence, even though each report itself presents a great deal of such evidence. In forthcoming analyses, the FCC would be better served by focusing more on the direct evidence and less on indirect (and far less informative) criteria such as market shares and industry concentration. Doing so would present a much clearer picture of competition in the wireless marketplace. In Parts III and IV, we examine the record of direct evidence of competitive conduct in the wireless service industry.

\section{DIRECT EVIDENCE OF WIRELESS PRICING DOES NOT SUGGEST MARKET POWER}

The FCC's own evidence shows that wireless providers have been cutting wireless prices to fend off rivals or what the report calls "price rivalry." 39 This is the opposite of the way monopolists behave. Indeed, the 14th Wireless Report outlines at least eight effective price cuts by wireless carriers:

1. AT\& $\mathbf{T}$ introduced its "A-List" calling feature, which allows unlimited mobile calling to and from any five "VIP" domestic phone numbers at no additional charge. ${ }^{40}$

2. Sprint introduced unlimited mobile-to-mobile calling at no additional charge. ${ }^{41}$

3. T-Mobile introduced a lower-priced version of its unlimited national voice calling plan, and it reset prices on tiered offerings at significant discounts to its legacy plans. ${ }^{42}$

4 and 5. Verizon Wireless reduced the prices of its unlimited voice plans for both individual and shared family offerings, prompting AT\& $\mathbf{T}$ to do the same. ${ }^{43}$

6, 7, and 8. "Sprint Nextel reduced the monthly charge on its Boost Unlimited voice and data plan to roughly half the price of the cheapest

price is what matters. As is stated in the Areeda, Elhauge, and Hovenkamp treatise, cases such as Microsoft, and the Areeda, Kaplow, and Edlin casebook, if power can be shown directly, there is no need for market definition: the value of market definition is in cases where power cannot be shown directly and must be inferred from sufficiently high market share in a relevant market.").

38. See, e.g., Luís M. B. CABral, InTROduction to Industrial Organization 6-11 (2000).

39. 14th Wireless Report, supra note 1, at para. 87.

40. Id. at para. 90 .

41. $I d$.

42. Id. at para. 91 .

43. Id. at para. 92 . 
postpaid version of an unlimited voice and data offering then available, ${ }^{, 44}$ which caused MetroPCS to enhance their respective unlimited local calling plans by reducing the monthly charges for addon features. ${ }^{45}$ Leap responded "with similar changes to the pricing of add-on features." ${ }^{46}$

The 15th Wireless Report illustrates other examples of price rivalry, including an important price reduction in 2009 by Sprint Nextel, "which allow[ed] unlimited mobile-to-mobile calling to any domestic wireless number, rather than a limited selection of designated wireless and wireline numbers. ${ }^{, 47}$ It also notes that the nationwide operators' movement into prepaid services "continues to put pressure on smaller traditional prepaid service providers to revamp their pricing plans and lower the prices of their own unlimited prepaid service offerings. ${ }^{.48}$ This is the epitome of competition.

Although the FCC reviewed this evidence of price rivalry in both reports, it failed to put appropriate weight on this type of evidence when assessing whether the wireless industry was competitively supplied. Moreover, the FCC appears to consider certain new services offerings as disadvantageous, including unlimited calling to a select group of numbers: "While the monthly bill remains unchanged, the additional features are designed to create a perception that consumers are getting more value for their money. ${ }^{, 49}$ Does this mean that the FCC believes that such features are of no value to customers? If so, the report does not explain the basis for this view. Generally, the FCC appears to be putting less weight on expressed customer preferences and more on its own subjective judgment regarding what constitutes added value.

The most recent significant price cut among national carriers occurred on January 15, 2010, when Verizon reduced its national unlimited voice plans by $\$ 30$ per month; AT\&T followed shortly thereafter with a nearly identical reduction in its national plans. ${ }^{50}$ AT\&T and Verizon were responding to the introduction of low-price unlimited plans by Leap

44. Id. at para. 102 (emphasis added).

45. Id. at para. 103 .

46. Id.

47. 15th Wireless Report, supra note 4, at para. 82 .

48. Id. at para. 83 (emphasis added).

49. 14th Wireless Report, supra note 1, at para. 90 (emphasis added).

50. Sinead Carew, Verizon, AT\&T Cut Fees, Expand Price War, ReuTERs (Jan. 15, 2010, 11:24 PM), http://uk.reuters.com/article/2010/01/15/us-verizon-idUKTRE60E2MI 20100115. 
(September 16, 2009) ${ }^{51}$ and by MetroPCS (January 12, 2010). ${ }^{52}$ Moreover, with a few exceptions, the Verizon and AT\&T price reductions occurred largely at the "high end" of the voice services marketplace. ${ }^{53}$ Leap and MetroPCS continued to offer service options at far lower prices than either Verizon or AT\&T. ${ }^{54}$

Other sources corroborate evidence of competitive pricing. According to the Bureau of Labor Statistics, the CPI for "wireless telephone services," there has been a downward trend since $2001 .^{55}$ The same basket of wireless services in January 2011 cost consumers 12 percent less than what it cost in January 2001, and 42 percent less than what it cost in January $1998 .{ }^{56}$ And because the CPI cannot easily account for increases in call quality, this index understates the true decrease in the quality-adjusted price of wireless telephony.

Wireless prices are not just declining for users who consume all-youcan-eat plans. The proliferation of post-paid plans with limited minutes and affordable pre-paid plans are addressing important segments of consumer demand. In Washington, D.C., for example, not including daily pre-paid plans, there were ten distinct wireless plans offered by five distinct carriers that cost less than $\$ 40$ per month in the summer of $2011 .^{57}$

In another analysis of wireless prices, Bank of America/Merrill Lynch Research reported that the average revenue per voice minute among U.S. wireless carriers was $\$ 0.04$ in the second quarter of 2010. Figure 2 shows the revenue per voice minute by country. ${ }^{58}$

51. See Phil Goldstein, Leap Launches New Plans, Expands Distribution, FIERCE WIRELESS (Sept. 16, 2009, 10:54 AM), http://www.fiercewireless.com/story/leap-launchingnew-plans-wider-retail-distribution/2009-09-16?utm_medium=rss\&utm_source=rss\&cmpid=OTC-RSS-FW0.

52. See Press Release, MetroPCS, MetroPCS Introduces Wireless for All Nationwide Serv. Plans with No Hidden Terms or Reg. Fees (Jan. 12, 2010), available at http://investor.metropcs.com/External.File?t=2\&item=g7rqBLVLuv81UAmrh20Mp1SQDr UR8+CcS+LduZS93g9u/U9GU3Ii4rpzOxT6eJx+vgeMbyJkN366UtDmy1TQpw==.

53. Carew, supra note 50 ("Some experts still believe the impact is limited. Pacific Crest Securities analyst Steve Clement said only about a million customers use Verizon's $\$ 99.99$ a month unlimited voice service today.”).

54. $I d$.

55. Bureau of Labor Statistics, U.S. Dept. of Labor, CPI Detailed Report 86 (April 2009), http://www.bls.gov/cpi/cpid0904.pdf.

56. See $i d$. at 79; see also BUREAU of LABOR StATISTICS, U.S. DePT. OF LABOR, CPI DETAILED REPORT (January 2011), http://www.bls.gov/cpi/cpid1101.pdf.

57. See infra app. 1.

58. Robert F. Roche, Vice President of Research, CTIA, Presentation at CTIA: U.S. Wireless Industry Overview, slide 20 (Aug. 4, 2010). 
Figure 2: Average Revenue Per Voice Minute, 2009

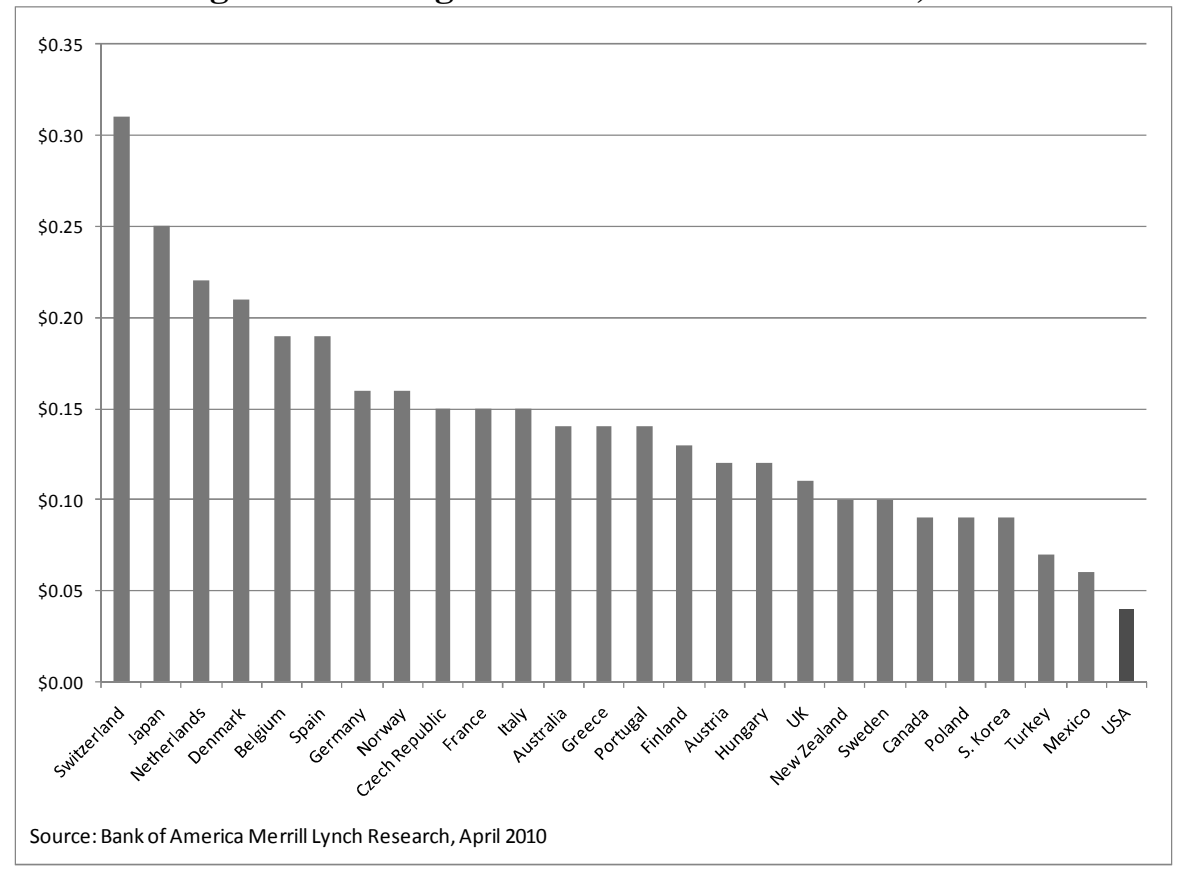

U.S. wireless prices are cheaper than everywhere else, including in very similar countries like Canada.

Indeed, some U.S. carriers are reporting declines in their ARPU, which usually indicates a lack of market power. According to SNL Kagan, all wireless carriers experienced reductions in voice ARPU (as opposed to data ARPU) from Q4 2009 through Q4 2010, with a weighted average decline across the industry of 10.9 percent. ${ }^{59}$ Total wireless ARPU (including voice and data revenue) similarly declined as illustrated in Table 1. Although AT\&T experienced a decline in total ARPU from 2008 to 2010 , its decline (1.8 percent) was smaller than its peers (3.9 percent to 19.5 percent), likely because AT\&T's subscribers consume more data services than non-AT\&T subscribers-that is, its increase in data ARPU partially offset its decline in voice ARPU. ${ }^{60}$

59. AT\&T led the way with a 10.2 percent reduction, followed by Verizon ( 8.2 percent reduction), T-Mobile (7.3 percent reduction), and Sprint Nextel (2.6 percent reduction). See John Fletcher, Wireless ARPUs Compared to Macroeconomic Indicators, SNL KaGAN, (Mar. 10, 2011).

60. Id. (noting that AT\&T reported the highest data revenue among its subscribers). 


\begin{tabular}{|l|l|l|l|l|}
\hline \multicolumn{5}{|c|}{ Table 1: Total Wireless ARPU } \\
\begin{tabular}{|l|l|l|l|}
\hline \multicolumn{5}{|c|}{201} \\
Carrier
\end{tabular} & 2008 & 2010 & $\begin{array}{l}\% \text { Change } \\
2008-2010\end{array}$ \\
\hline Leap Wireless & 43.52 & 40.26 & 37.76 & $-13.2 \%$ \\
\hline MetroPCS & 41.39 & 40.68 & 39.79 & $-3.9 \%$ \\
\hline Sprint Nextel Corporation & 53.25 & 43.25 & 42.85 & $-19.5 \%$ \\
\hline $\begin{array}{l}\text { Verizon Communications, } \\
\text { Inc. }\end{array}$ & 51.59 & 48.94 & 46.62 & $-9.6 \%$ \\
\hline AT\&T Inc. & 50.60 & 50.63 & 49.68 & $-1.8 \%$ \\
\hline T-Mobile & 51.25 & 47.25 & 46.50 & $-9.3 \%$ \\
\hline
\end{tabular}

These declining-price data are consistent with a recent GAO report that calculated that wireless prices declined 50 percent from 1999 to $2009 .^{62}$ Another analysis by Recon Analytics estimated that the average monthly bill for wireless services declined from $\$ 47.46$ in 2005 to $\$ 33.02$ in 2010, a decline of roughly one-third. ${ }^{63}$

Prices for text messaging are also declining. According to Nielsen, the effective price per text message declined from approximately $\$ .06$ to $\$ .01$ from 2005 to $2010 .{ }^{64}$ Nielsen also reports that since 2008 the cost of data

61. John Fletcher, Wireless ARPUs Compared to Macroeconomic Indicators, SNL (Mar. 10, 2010, 7:10 PM), http://www.snl.com/interactivex/article.aspx?id=124638 8\&KLPT=6; SNL, LEAP WIRELESS 2010 ANNUAL REPORT (2010); METROPCS: WIRELESS FOR ALL: ANNUAL REPORT 2010 (2010); SNL, LEAP WIRELESS 2009 ANNUAL REPORT (2009); SNL, METROPCS: WIRELESS FOR ALL: ANNUAL REPORT 2009 (2009); SNL, LEAP WIRELESS 2008 ANNUAL REPORT (2008); SNL, METROPCS: WiRELESS FOR ALL: ANNUAL REPORT 2008 (2008).

62. U.S. Gov't AcCountability OfFice, Highlights of GAO-10-779, Telecommunications: Enhanced Data Collection Could Help FCC Better Monitor COMPETITION IN THE WIRELESS INDUSTRY (2010).

63. Roger Entner, Entner: What Is the Price of a Megabyte of Wireless Data?, FIERCE WiRELESS (Apr. 13, 2011, 9:18 PM), http://www.fiercewireless.com/story/entner-whatprice-megabyte-wireless-data/2011-04-13.

64. Id. (citing Nielsen Customer Value Metrics, effective price per message). 
services has declined nearly 90 percent from $\$ 0.47$ per MB down to only $\$ 0.05$ per MB. ${ }^{65}$ Figure 3 depicts these price declines.

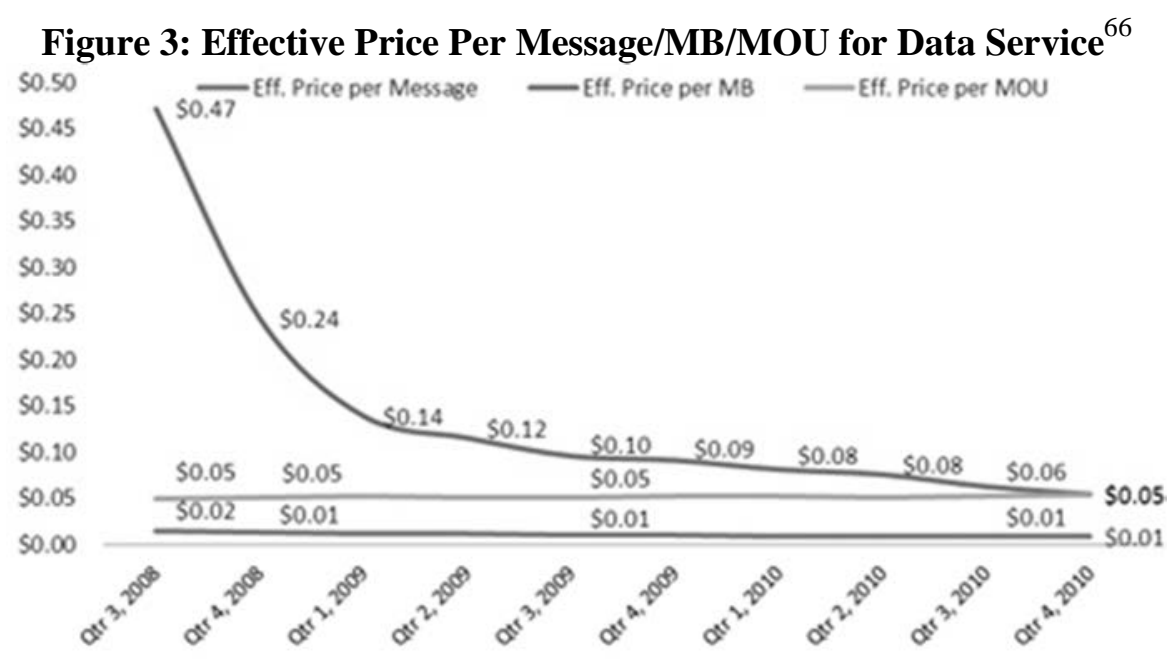

Even more impressively, these price declines have occurred despite wireless usage increasing dramatically. ${ }^{67}$ CTIA recently reported that billable minutes of use amounted to roughly 2.3 trillion for the last twelve months ending in June $2010,{ }^{68}$ up 1 percent year-to-year, and that SMS/text messages amounted to 1.8 billion for the last twelve months ending in June $2010,{ }^{69}$ up 33 percent year-to-year. Data traffic increased 50 percent to 161.5 billion MB in the first six months of $2010 .^{70}$

Another measure of the growing usage in wireless is handset sales. A recent report by Strategy Analytics demonstrates that the United States leads the world in smartphone sales with sales estimated at $\$ 100$ million in 2011. ${ }^{71}$ The United States also leads the world in mobile broadband

65. Id. (citing Nielsen Customer Value Metrics, effective price per unit).

66. Id.

67. Over the short run, accommodating demand increases is expensive and generally forces unit costs upwards (assuming upward sloping short-run supply curves), which can lead to higher wireless prices. Over the long run, carriers may be able to invest to expand their networks and bring unit costs back down, but spectrum scarcity will always limit this ability.

68. 50 Wireless Quick Facts, CTIA ADVOCACY, http://www.ctia.org/advocacy/research /index. cfm/AID/10377 (last visited Feb. 20, 2012).

69. Id.

70. $I d$.

71. Thomas Kang, Strategy Analytics, Global Smartphone Sales Forecast by Country: Americas, StRATEgy AnAlytics (Sept. 12, 2011), http://www.strategyanalytics.com/ default.aspx?mod=reportsabstractviewer\&a0-6665. 
subscribers with 2011 mobile broadband subs of 203 million. $^{72}$ The FCC incorrectly suggests that U.S. mobile penetration "is lower than average mobile penetration in Western Europe" $" 3$ by citing a penetration metric that measures SIM cards, not the actual number of wireless customers. Given the predominance of pre-paid service in Europe, however, an individual customer may hold several unexpired SIM cards. Europeans may also have multiple SIM cards for use in traveling to different countries, making comparisons based on SIM card count misleading. ${ }^{74}$ That wireless prices have declined in spite of an outward shift in demand suggests that the wireless carriers have failed to restrict supply, a hallmark of market power.

Many of these pricing metrics and usage statistics are captured in the 15th Wireless Report. For example, the report demonstrates that voice revenue per minute has consistently declined for much of the last two decades, ${ }^{75}$ including a decline of 9 percent from 2008 to $2009 .{ }^{76}$ Price per text dropped for the fifth consecutive year, falling by 25 percent in $2009 .^{77}$ The price per megabit of data traffic dropped even more dramatically. ${ }^{78}$ Overall, ARPU also declined from $\$ 47.09$ in 2008 to $\$ 45.85$ in $2009 .^{79}$ With regard to increased usage, the report notes that wireless connections and wireless internet access subscribers increased in $2009 ;{ }^{80}$ devices in use capable of $200 \mathrm{kbps}$ and higher increased in $2009 ;{ }^{81}$ and adoption rates across mobile data services are up. ${ }^{82}$

Given the impressive direct evidence on wireless pricing, it is difficult to understand the FCC's recent reluctance to conclude that U.S. wireless markets are effectively competitively supplied. As demonstrated next, any contrary view cannot be defended on the basis of exclusion either, as myriad new providers have entered the wireless market.

72. OECD, Broadband Statistics (June 2011).

73. 14th Wireless Report, supra note 1, at 11428.

74. Mobile Operators Start to See Double, Consult STRAND, http://www.strandreports.com/sw2297.asp (last visited Jan. 20, 2012). Wireless penetration in the United States, defined as the number of active units divided by the total United States and territorial population, reached 96 percent in December 2010. See U.S. Wireless Industry-Quick Facts, supra note 68. Although many European nations enjoy penetration rates in excess of 100 percent-that is, more units than population-differences at those levels are not as economically meaningful. Id.

75. 15th Wireless Report, supra note 4, at 9784 tbl.20.

76. $I d$.

77. Id. at para. 193 (citing Morgan Stanley).

78. Id. at para. 194 (citing AT\&T's price per MB of data traffic for 2008 through 2010).

79. Id. at para. 203.

80. Id. at para. 158 .

81. Id. at para. 161 .

82. Id. at paras. 9763-64 charts 8-9. 


\section{DiReCt EVIDENCE OF ENTRY By NeW SuPPLIERS DOES Not SUGGEST MARKET POWER}

A second direct measure of market power is the ability to exclude rivals. If incumbents are successful at excluding rivals, then we should observe foreclosure-induced exit and no entry. Although some firms have been acquired (Centennial and Alltel), we are not aware of any evidence of forced exit due to the withholding of a critical input by an incumbent carrier, and entry into the wireless services market has been robust. In the 14th Wireless Report, the FCC considered entry by several firms to represent "commitments that are large enough to be consistent with entry that could introduce new competitive constraints at the regional or national level." ${ }^{83}$ (The 15th Wireless Report used nearly the identical language.) ${ }^{84}$ In particular, the FCC described the entry by Clearwire, ${ }^{85}$ Leap, MetroPCS, and Cox as economically significant. ${ }^{86}$ The FCC's appraisal is corroborated by investment analysts like J.P. Morgan Equity Research, which explained that the wireless industry "remains one of high and aggressive competition," with each market served by "an average of 5 to 6 players," and that Clearwire and LightSquared " ${ }^{87}$ "represent two potential new

83. 14th Wireless Report, supra note 1, at para. 68

84. 15th Wireless Report, supra note 4, at para. 67 ("Below we summarize entry commitments that are large enough to be consistent with entry that could introduce new competitive constraints at the regional or national level.").

85. Although Clearwire reported capital issues in mid-2011, these are likely overwrought. See Gary Kim, Clearwire: Bankruptcy Cannot Be Discounted, NexT GENERATION COMM. (Mar. 25, 2011), http://next-generation-communications.tmcnet.com/ topics/nextgen-voice/articles/158005-clearwire-bankruptcy-cannot-be-discounted.htm. Even if Clearwire is under financial pressure, the capacity from its wireless network-and the resulting downward pressure on wireless prices-will not go away, even in the event of a bankruptcy.

86. 14th Wireless Report, supra note 1, at paras. 68-69, 72-73. In May 2011, Cox announced that it planned to decommission its own network build, and to become a Sprint mobile virtual network operator. Karl Bode, Cox Scraps Wireless Build, Will Stick to Sprint MVNO, DSL REPORTS (May 24, 2011), http://www.dslreports.com/shownews/Cox-ScrapsWireless-Build-Will-Stick-to-Sprint-MVNO-114374?nocomment=1.

87. In early June 2011, LightSquared acknowledged interference problems with some GPS systems, but maintained that technical solutions were available. See Amy Schatz, House Members Take GPS Worries to FCC, Wall ST. J. (June 7, 2011, 7:33 PM), http://blogs.wsj.com/washwire/2011/06/07/house-members-take-gps-worries-to-fcc/. By late June 2011, the company announced that "it will use a lower-frequency chunk of its $10 \mathrm{MHz}$ block of spectrum, further away from the GPS frequencies, and lower the maximum authorized power of its base stations by more than 50\%." John Cox, LightSquared Proposes Spectrum Change to Allay GPS Concerns, NETWORK WORLD (June 24, 2011, 9:52 AM), http://www.networkworld.com/news/2011/062411-lightsquared-spectrum-change.html?hpg 1=bn. See also Phil Cusick, U.S. Telecom Services \& Towers, J.P MoRGAN EQUITY RESEARCH 10 (Jan. 13, 2011), https://www.gazhoo.com/upload/document/2011/01/26/ 201101260521185412.swf. 
entrants that may have a lower cost structure than incumbent players. This last point on cost advantages is important: To the extent that Clearwire and LightSquared's costs are less than the incumbent carriers, economic theory would suggest that wireless prices are heading even lower.

As it did with the pricing evidence, the 14th and 15th Wireless Reports ably summarize the evidence on entry. According to the FCC, Clearwire is not some fly-by-night entrant: It enjoys financial support from Sprint Nextel, Comcast and Google. ${ }^{89}$ Leap and MetroPCS are, according to the 14th Wireless Report, making "important" entry into new geographic markets. ${ }^{90}$ The 15 th Wireless Report devotes subsections to Clearwire, Leap and MetroPCS, Atlantic Tele-Network, and Cox in its section detailing committed entry in the wireless market. ${ }^{91}$ Yet this direct evidence of entry is downplayed in both reports, while the (indirect) market share measures are highlighted.

New players are emerging with different models and networks. For example, LightSquared's hybrid satellite-terrestrial network and wholesale business model could provide an advantage for firms like Leap and Clearwire. Even regional carriers like U.S. Cellular seem poised to expand and increase competition. ${ }^{92}$ These entrants, some of whom hold large amounts of unused spectrum, could soon offer technologically cutting-edge services, which makes their entry all the more disruptive.

\section{A. Clearwire}

Clearwire has significant holdings of $2.5 \mathrm{GHz}$ spectrum nationwide. ${ }^{93}$ Clearwire itself touts this strong spectrum position as providing a "unique

88. Cusick, supra note 87, at 10.

89. 14th Wireless Report, supra note 1, at para. 69. As of December 2010, Sprint held approximately 53.9 percent of the voting power of Clearwire; Google held approximately 3.0 percent of the voting power of Clearwire; Intel held approximately 10.3 percent of the voting power of Clearwire; Time Warner Cable held approximately 4.7 percent of the voting power of Clearwire; and Comcast held 8.9 percent of the voting power of Clearwire. Clearwire Corp., Annual Report Pursuant to Section 13 or 15(D) of the Securities $\begin{array}{lllllll}\text { EXCHANGE ACT } & \text { OF } & 1934 & 4 & \text { (2011), available at }\end{array}$ http://corporate.clearwire.com/common/down $=$ CLWR\&fid=950123-11-16614\&cik=1442505.

90. 14th Wireless Report, supra note 1, at para. 72.

91. 15th Wireless Report, supra note 4, at paras. 68-72.

92. In the first quarter of 2010, U.S. Cellular reversed its previous two quarters of subscriber losses, bringing its total subscribers to 6.14 million. Phil Goldstein, U.S. Cellular Appoints New CEO, Posts Weaker Subscriber Growth, FIERCE WIRELESS (May 10, 2010, 11:02 AM), http://www.fiercewireless.com/story/u-s-cellular-appoints-new-ceo-postsweaker-subscriber-growth/2010-05-10.

93. 14th Wireless Report, supra note 1, at para. 69. 
and sustainable advantage" over competitors. ${ }^{94}$ Clearwire's service offerings currently consist of voice service (VoIP) and wireless data services (both fixed and mobile). As of April 2011, Clearwire had approximately 4.4 million subscribers (of which 3.3 million were wholesale subscribers through Clearwire investors); ${ }^{95}$ Clearwire's $4 \mathrm{G}$ network was available in seventy-one cities across the United States and covered an estimated 120 million people, including major metropolitan areas such as Atlanta, Boston, Chicago, Dallas, Houston, Los Angeles, New York, San Francisco, and Washington, D.C. ${ }^{96}$

\section{B. Leap Wireless (Cricket)}

Leap has enjoyed impressive growth. In the first quarter of 2011, Leap enjoyed faster subscriber growth than either AT\&T or Verizon. ${ }^{97}$ The carrier competes against larger rivals by offering unlimited national voice and data plans to customers who seek low rates and flexible contract lengths. Sprint Nextel views Leap (along with MetroPCS, reviewed below) as a legitimate competitor, no longer as a fringe player. ${ }^{98}$

94. Clearwire's Thoughts on Unlimited Data Plans and Tiered Pricing, CLEAR (Jun. 8, 2010, 9:11 AM), http://clear.com/blog/clearwires-thoughts-on-unlimited-data-plans-andtiered-pricing/ (noting that its "cost efficient, high capacity, and highly-scalable all IPnetwork backbone, combined with our unmatched spectrum position gives us a unique and sustainable advantage to serve our retail and wholesale businesses.").

95. Todd Spangler, Clearwire, Comcast and Sprint Widen 4G Reach to D.C, Baltimore, Multichannel News (Apr. 20, 2011, 5:39 PM), http://www.multichannel.com/article/ 467098-Clearwire_Comcast_And_Sprint_Widen_4G_Reach_In_D_C_Baltimore.php.

96. Press Release, Clearwire, Clearwire and Locus Communications Announce New 4G Wholesale Agreement (Apr. 7, 2011), available at http://corporate.clearwire.com/ releasedetail.cfm?ReleaseID=563465; ClEARwIRE CORP., ANNUAL REPORT (FORM 10-K) $2-$ 3, 6-8 (Feb. 24, 2010), available at http://corporate.clearwire.com/common/download/ sec.cfm? companyid=CLWR\&fid=950123-10-16444\&cik=1442505.

97. Leap reported 331,000 net adds in the first quarter of 2011 , bringing its total subscribers to 5.84 million for an increase of 6.01 percent from its December 2010 subscribers. Phil Goldstein, Leap Adds Fewer Subscribers in Q1, but Improves Churn, FIERCEWIRELESS (May 4, 2011, 4:34 PM), http://www.fiercewireless.com/story/leap-addsfewer-subscribers-q1-improves-churn/2011-05-04. Verizon reported 1.8 million net adds for the first quarter of 2011, bringing its total subscribers to 104 million for an increase of 1.76 percent from its December 2010 subscribers. AT\&T reported 2 million net adds in the first quarter of 2011, bringing its total subscribers to 97.5 million for an increase of 2.09 percent from its December 2010 subscribers. Sue Marek, Verizon Activated 2.2M iPhones in Q1, Sees Strong ThunderBolt Demand, FIERCEWIRELESS (April 21, 2011, 10:53 AM), http://www.fierce wireless.com/story/verizon-activates-22m-iphones-q1-sees-strongthunderbolt-demand/ 2011-04-21.

98. SEC, Sprint NeXtel Corp. Annual Report (Form 10-K) 3 (2010), available at http://www.google.com/url?sa=t\&rct=j\&q=\&esrc=s\&source=web\&cd=2\&ved=0CDoQFjA B\&url=http $\% 3 \mathrm{~A} \% 2 \mathrm{~F} \% 2 \mathrm{Fphx}$.corporate-ir.net\%2FExternal.File\%3Fitem\%3DUGFyZW50 SUQ9ODQwMjZ8Q2hpbGRJRD0tMXxUeXBIPTM\%3D\%26t\%3D1\&ei=YoNCT5WBDur c0QGL8rX_DA\&usg=AFQjCNEfgG8Cd4rUTGiR5bRne0G5gPMG9g\&sig2=7ANgzwnha 
Mostly through its Cricket subsidiary, Leap offers wireless service in thirty-five states covering 100 million people. ${ }^{99}$ Leap hopes to rapidly expand to cover 280 million people in all fifty states. ${ }^{100}$ As of January 2012, Leap had 6 million wireless subscribers, ${ }^{101}$ and it held spectrum in thirty-five of the fifty largest U.S. markets. ${ }^{102}$ The 14th Wireless Report documented Leap's impressive rise over the past several years, noting that Leap expanded its coverage by 26.6 million people from 2008 to 2009 (from 53.9 million to 80.5 million). ${ }^{103}$

Even more important, Leap has positioned itself as a low-cost provider, which makes it all the more difficult for its larger rivals to raise prices. Nearly 80 percent of Cricket customers are living in households earning less than $\$ 50,000$ a year. ${ }^{104}$ Leap represents a decidedly different option for customers not interested in becoming AT\&T or Verizon subscribers. Indeed, Leap highlights this difference in its marketing materials, including the slogan "half the cost of AT\&T and Verizon."

In addition, Leap has targeted data-intensive subscribers. ${ }^{106}$ Leap has seen significant increases in smartphone adoption by its customer base in

VlkNgscyrJWow ("Our prepaid services compete with several regional carriers, including Metro PCS and Leap Wireless, which offer competitively-priced prepaid calling plans that include unlimited local calling.").

99. Mike Freeman, Leap Wireless' Cricket Hops on to National Stage, SAN DiEGO UnION-TRIB. (Sept. 12, 2010 7:38 PM), http://www.signonsandiego.com/news/2010/sep/ 12/leap/.

100. 14th Wireless Report, supra note 1, at para. 72 ("Leap, which holds many PCS licenses and AWS licenses (acquired at the 2006 auction) in markets throughout much of the country ....."); see also id. ("expanding its potential subscriber base from around 100 million people in 35 states to 280 million people in all 50 states.").

101. See Company Information, CRICKET, http://www.mycricket.com/learn/companyinformation (last accessed on Jan. 13, 2012).

102. LEAP WiRELESS INT'L, ANNUAL REPORT (Form 10-K) 3 (March 1, 2010), available at http://investor.leapwireless.com/phoenix.zhtml?c=95536\&p=irol-sec (select "Annual Filings" in "Groupings Filter" box; then click "Search"; then click button corresponding to desired document format on line for Mar, 1, 2010 10-K form).

103. 14th Wireless Report, supra note 1, at para. 72 .

104. Freeman, supra note 99.

105. See Android Smartphone, CRICKET, http://www.mycricket.com/smartphones/ android (last visited Feb. 20, 2012).

106. Press Release, Leap Wireless Int'l, Cricket Enters into 4G Agreement with LightSquared (Mar. 22, 2011), available at http://leapwireless.mediaroom.com/index. php?s=13383\&item=30563 ("Our business progress demonstrates how data services are increasingly important to our customers, as evidenced by our customers' significant uptake of smartphones and data-focused, higher-ARPU service plans. We intend to deploy our own LTE networks beginning this year to complement the existing nationwide $3 \mathrm{G}$ services we currently offer to customers. This new roaming arrangement will allow us to offer customers an even-greater 4G service area as LightSquared expands its own network." (quoting Doug Hutcheson, Leap's President and CEO). 
2010, with 10 percent of subscribers moving to smartphones in the fourth quarter of 2010, accounting for 40 percent of new handset sales. ${ }^{107}$ As of 2010, Leap offered $3 \mathrm{G}$ service in all of its markets, covering around 92 million people, and through an agreement with Sprint, Leap covers 280 million people with $3 \mathrm{G}$ service. ${ }^{108}$

As of April 2011, Leap was testing 4G services, and it entered into an agreement with LightSquared, a commercial wholesaler, to offer $4 \mathrm{G}$ roaming services outside of its footprint. ${ }^{109}$ Leap hopes to launch its commercial $4 \mathrm{G}$ trial in late $2011 .^{110}$

\section{MetroPCS}

Like Leap, MetroPCS has been expanding its offerings rapidly. MetroPCS ended the first quarter of 2011 with more than 8.8 million subscribers, an increase of 726,000 subscribers relative to the fourth quarter of 2010. ${ }^{111}$ Since 2002, MetroPCS has increased its customer base by nearly 1,500 percent. ${ }^{112}$ MetroPCS holds PCS and AWS spectrum throughout the United States, and it has been rapidly expanding its coverage to 90 percent of the United States. ${ }^{113}$ In September 2008, MetroPCS signed a long-term deal with Leap, and it now offers service for a flat monthly fee without any roaming charges. ${ }^{114}$ MetroPCS offers nationwide coverage through its Metro USA nationwide service. ${ }^{115}$ From

107. Mike Dano, Leap Plans Wi-Fi-only ViewSonic Android Tablet, More Android Smartphones, FIERCEWIRELESS (Mar. 24, 2011, 2:53 PM), http://www.fiercewireless.com/ ctialive/story/leap-plans-wi-fi-only-viewsonic-android-tablet-more-android-smartphones/ 2011-03-24.

108. Press Release, Leap Wireless Int'1, Cricket Enters into National 3G Data Roaming Agreement (Aug 3, 2010), available at http://phx.corporate-ir.net/phoenix.zhtml.

109. Cricket Enters into 4G Roaming Agreement with LightSquared, supra note 106.

110. LEAP Wireless InT' L, ANNUAL RePORT, supra note 102, at 3.

111. Grading the Top Ten Carriers in the First Quarter of 2011, FIERCEWIRELESS, http://www.fiercewireless.com/special-reports/grading-top-10-us-carriers-first-quarter-2011 (last visited Feb. 20, 2012).

112. See Metro PCS, Presentation at the Bank of America Credit Conference slide 12 (Nov. 17, 2010), http://phx.corporate-ir.net/External.File?item=UGFyZW50SUQ9NDA3Mj Y1fENoaWxkSUQ9NDE2NjIzfFR5cGU9MQ==\&t=1.

113. See 14th Wireless Report, supra note 1, at paras. 72, 155.

114. See Press Release, MetroPCS, Leap Wireless International, Inc. and MetroPCS Communications, Inc. Enter into National Roaming Agreement and Spectrum Exchange Agreement and Settle Litigation (Sept. 29, 2008) (on file with MetroPCS Communications, Inc. and Leap Wireless International, Inc).

115. MetroPCS has nationwide service, covering 280 million POPS and over 8 million subscribers. See MetroPCS Communications' CEO Discusses Q1 2011 Results - Earnings Call Transcript, SEeKING AlPHA (May 3, 2011, 9:00 A.M.), http://seekingalpha.com/ article/267282-metropcs-communications-ceo-discusses-q1-2011-results-earnings-calltranscript. 
October 2008 through October 2009, MetroPCS expanded its coverage from 56 million to 84.6 million people (an increase of 28.6 million potential subscribers). ${ }^{116}$ MetroPCS believes that it has a footprint that rivals or exceeds that of Sprint. ${ }^{117}$

MetroPCS offers low-cost plans that place significant pricing pressure on its rivals. Its "Wireless for All" plan, which ranges from forty dollars to sixty dollars per month, has made significant inroads in the marketplace. ${ }^{118}$ Because it enjoys such low incremental costs (one estimate places its costs at less than twenty dollars per month), MetroPCS can offer lower prices while maintaining profitability. ${ }^{119}$ Although MetroPCS has a smaller subscriber base than AT\&T or Verizon, as the low-cost pricing plan in the marketplace, the disparity in size should decrease over time. (The same is true for Leap.) Like any new product, it takes time for an advertising campaign to work and for customers to consider new options.

MetroPCS is also pushing the boundaries of high-speed data service. In fact, MetroPCS is the first carrier in the United States to offer Long Term Evolution ("LTE") service to its customers, and it has expanded its 4G coverage to Tampa, Atlanta, Jacksonville, Miami, Orlando, Boston, Dallas-Fort Worth, Detroit, Las Vegas, Los Angeles, New York, Philadelphia, Sacramento, and San Francisco. ${ }^{120}$ The company seeks to finish "phase-1" 4G-LTE buildout sometime in 2011, and it will complete "phase-2" of the buildout by the end of 2012-by which point MetroPCS will carry LTE on all of its 11,000 cell sites. ${ }^{121}$ Further, MetroPCS offers

116. 14th Wireless Report, supra note 1, at 11440 tbl.1.

117. MetroPCS CFO Braxton Carter stated recently that MetroPCS has a footprint that "is actually a tad bit larger than the Sprint network." Final Transcript, PCS-MetroPCS Communications, Inc. at Raymond James Institutional Investors Conference at 1 (Mar. 10, 2011), available at http://www.alacrastore.com/research/thomson-streetevents-MetroPCS_ Communications_Inc_at_Raymond_James_Institutional_Investors_Conference-T3753643.

118. Sarah Reedy, MetroPCS Snares Share From T-Mobile, Light Reading Mobile (Mar. 7, 2011), http://www.lightreading.com/document.asp?doc_id=205297.

119. Scott Woolley, The Upstart Company that Made the AT\&T-mobile Merger Possible, FORTUNE (Mar. 22, 2011), http://tech.fortune.cnn.com/2011/03/22/the-upstartcompany-that-made-the-att-mobile-merger-possible/. See also WiKINVEST, MetroPCS Communications (NYSE: PCS), http://www.wikinvest.com/stock/MetroPCS_(PCS) ("Furthermore, MetroPCS' attention on densely populated urban markets has helped it achieve the highest margins (14.5\% operating margin in 2009) and customer growth rate ( $42 \%$ annual) in the wireless industry over the past three years by keeping distribution and capital expenditures per potential customer low.") (last visited Feb. 20, 2012).

120. Press Release, MetroPCS, MetroPCS Launches First 4G LTE Services in the United States and Unveils World's First Commercially Available 4G LTE Phone (Sept. 21, 2010), available at http://multivu.prnewswire.com/mnr/metropcs/46037/; Press Release, MetroPCS, MetroPCS Launches 4G LTE Service in the Tampa Metropolitan Area (Apr. 1, 2011) (on file with MetroPCS Communications, Inc.).

121. Mike Dano, MetroPCS Details LTE Buildout Plans for 2011, Open to 
cutting-edge smartphones with access to its quickly expanding 4G network. ${ }^{122}$ Further, because LTE uses spectrum far more efficiently than 3G services, MetroPCS can not only offer high-end wireless services on a faster network, but it will also have the spectrum resources to satisfy its growing number of $4 \mathrm{G}$ subscribers and increased voice and text messages. ${ }^{123}$

In sum, both Leap and MetroPCS are becoming major players in the wireless industry. The two firms together cover over two-thirds of the U.S. population, and they serve twenty-one of the top twenty-five markets nationwide. Because Leap and MetroPCS have complimentary coverage, their roaming agreement is all the more powerful. ${ }^{124}$ As one analyst put it, through their roaming agreement, Leap and MetroPCS have effectively formed "the fifth nationwide carrier." 125 In fact, Verizon estimates that Leap and MetroPCS have achieved "penetration rates of between 8 and 13 percent in markets where they have been active for five or more years." According to prior CMRS Competition Reports, the business models of Leap and MetroPCS are so compelling that the larger rivals mimicked their "all you can eat" service plans that are month-to-month at a flat rate. ${ }^{127}$ It is

LightSquared, FIERCEWIRELESS (Sept. 22, 2010, 1:30 PM), http://www.fiercewireless.com/ story/metropcs-details-lte-buildout-plans-2011-open-lightsquared/2010-09-22.

122. SEC, MetroPCS Comm. Inc. 2010 Annual Report (Form 10-K) 6 (2011) ("We introduced the first commercial 4G LTE service in the United States in our Las Vegas and Dallas/Fort Worth metropolitan areas in September 2010 and launched the world's first dual mode 4G LTE/CDMA handset.").

123. See Letter from Carl W. Northrop, Paul, Hastings, Janofsky \& Walker LLP, to Julius Genachowski, FCC Chairman, GN Docket No. 09-191 (Preserving the Open Internet) and WC Docket No. 07-52 (Broadband Industry Practices), 6-7 (Feb. 14, 2011), available at $\mathrm{http}: / /$ fjallfoss.fcc.gov/ecfs/document/view.action?id=7021029361.

124. See Wireless Nationwide Coverage Maps, CRICKET, http://www.mycricket.com/ coverage/maps/wireless (last visited Feb. 20, 2012); MetroPCS, ANNUAL REPORT (FORM 10K) 10 (Mar. 1, 2011). Bernstein Research stated that the roaming agreement between the MetroPCS and Leap was "an essentially costless network expansion for both, since they both had a similar number of covered POPs with minimal overlap - hence, the cost of accommodating the other's roaming traffic roughly balanced the benefit of being able to double their coverage." Bernstein Research, Leap Wireless and MetroPCS: The Low End is Where the Action Is (Apr. 12, 2010), at 6 (emphasis added).

125. Hance Haney, Bailout for Sprint, Tech. \& Democracy Project (Aug. 3, 2011), http://www.disco-tech.org/2011/08/bailout_for_sprint.php.

126. 14th Wireless Report, supra note 1, at para. 72 n.175 (citing the Verizon Wireless PN Comments at 4).

127. Annual Report and Analysis of Competitive Market Conditions with Respect to Commercial Mobile Services, Twelfth Report, 23 F.C.C.R. 2241, para. 113 (Feb. 4, 2008) ("More recently, a number of operators have been experimenting with 'unlimited' calling options. As discussed in the Eleventh Report, some U.S. providers, including Alltel ('My Circle') and T-Mobile ('myFaves'), allow subscribers unlimited free calling to and from a small number of designated numbers, regardless of wireline or wireless carrier. Other providers offer plans that provide for free calls only to customers who use the same wireless 
precisely this ability to force competitors to follow pricing cuts that enables firms to significantly alter the competitive landscape for years to come.

\section{LightSquared}

LightSquared expects to cover 260 million people in the United States with its wireless broadband network by $2015 .{ }^{128}$ LightSquared will operate as a wholesale supplier to carriers looking to create or expand LTE wireless broadband coverage. ${ }^{129}$ LightSquared plans on covering the entire nation with 4G LTE service. ${ }^{130}$ Relative to a carrier like MetroPCS (which holds between 10 and $40 \mathrm{MHz}$ of spectrum depending on the market), LightSquared currently has a significant spectrum position with $59 \mathrm{MHz}$ of 1.6 GHz spectrum nationwide. ${ }^{31}$ LightSquared will assist upstart carriers by providing them access to a high quality 4G network. In March 2011, LightSquared entered into an agreement with Leap to supply LTE roaming services. ${ }^{132}$ In June 2011, LightSquared was close to completing a networksharing agreement with Sprint, under which "LightSquared would pay \$2 billion a year to rent space on Sprint's network to launch its own highspeed wireless services." ${ }^{, 133}$ Currently, LightSquared hopes to cover 100 million people by the end of 2012 , on route to its target of 260 million by

provider ('on-net' mobile-to-mobile options). A number of smaller and regional carriers, like Leap and MetroPCS, have been offering unlimited local calling plans for years. Now, first among the nationwide carriers, Sprint Nextel has begun offering unlimited calling plans, for a limited time, in select markets.").

128. Nationwide LTE Broadband Network, LiGHTSQUARED, http://www.lightsquared .com/what-we-do/network/ (last accessed Feb. 20, 2012).

129. Id.

130. See Lynnette Luna, FCC Grants LightSquared Satellite Waiver, FIERCEWIRELESS (Jan. 27, 2011, 1:35 AM), http://www.fiercebroadbandwireless.com/story/fcc-grantslightsquared-satellite-waiver/2011-01-27.

131. See Press Release, LightSquared, LightSquared Delivers Notice to Inmarsat Triggering Phase 2 of Re-Banding of L-Band Spectrum in North America (Jan. 28, 2011), available at http://www.lightsquared.com/press-room/press-releases/lightsquared-deliversnotice-to-inmarsat-triggering-phase-2-of-re-banding-of-1-band-spectrum-in-north-america/ ("When Phase 2 is fully executed, LightSquared will have the use of up to $59 \mathrm{MHz}$ of terrestrial and L-Band ATC spectrum over the continental United States and Canada to operate its nationwide integrated 4G-LTE and satellite network.").

132. Dan Jones, CTIA 2011: LightSquared Leaps Into Best Buy Deal, LiGHT READING (Mar. 23, 2011), http://www.lightreading.com/document.asp?doc_id=205971\&f_src= lightreading_gnews ("LightSquared also inked an LTE roaming deal with Leap Wireless International Inc. . . . on Tuesday. Leap's low-cost unit, Cricket Communications Inc. , [sic] however, still has to build out a $4 \mathrm{G}$ network to roam with the LightSquared offering in the first place.").

133. LightSquared, Near 2bln a Year Sprint Deal-sources, REUTERS (June 1, 2011 12:51 PM), http://www.reuters.com/article/2011/06/01/sprint-lightsquared-idUSN011686672011 0601 . 
2015. ${ }^{134}$ As of the first quarter of 2011, the company had entertained partnerships with more than sixty companies (fifteen of which are beyond initial negotiations), including Time Warner Cable. ${ }^{135}$

\section{E. Super Regional Carriers (U.S. Cellular, Cellular South, and Atlantic Tele-Network)}

Large regional carriers, called "Super Regionals," have also expanded their existing services, which further undermines any hint of exclusion by incumbent carriers. Also referred to as "non-nationwide service providers," 136 Super Regionals offer service regionally, but, through roaming agreements, they offer their customers the ability to call from anywhere in the country. As of 2011, U.S. Cellular served twenty-six states and 6.1 million subscribers (95 percent of which are contract customers). ${ }^{137}$ Some of the major metropolitan areas served by U.S. Cellular are Madison, Milwaukee, Oklahoma City, and St. Louis. ${ }^{138}$ U.S. Cellular provides $3 \mathrm{G}$ services to approximately 98 percent of its subscriber footprint, and it has announced plans to test LTE in late 2011, with a full launch coming by 2012. ${ }^{139}$ The initial launch was announced to occur in two dozen markets in time for the 2011 holiday season. ${ }^{140}$ The company plans to grow a new line of LTE devices and service offerings as it expands its network into new markets. ${ }^{141}$

Cellular South, Inc. is another Super Regional carrier, with a focus on the southeastern part of the United States. ${ }^{142}$ The company currently has

134. Marguerite Reardon, LightSquared Scores 4G Deal with Best Buy, CNET NEws (Mar. 23, 2011， 9:27 AM), http://reviews.cnet.com/8301-12261_7-2004620810356022.html.

135. Phil Goldstein, LightSquared CEO: We're in Contract Negotiations with 15 Companies, FiERCEWIRELESS (Mar. 28, 2011 9:19 AM), http://www.fiercewireless.com/ story/lightsquared-ceo-were-contracts-talks-15-companies/2011-03-28.

136. 14th Wireless Report, supra note 1, at para. 30.

137. U.S. Cellular Corporation, Annual Report (Form 10-K) 1 (Feb. 25, 2010).

138. Voice and Data Maps, U.S. Cellular, http://www.uscellular.com/coveragemap/voice-and-data-maps.html (last visited Feb. 20, 2012).

139. Id. at 7; Mike Dano, U.S. Cellular Plans LTE Test, Vendor Selection Next Year FiERCEWIRELESS (Nov. 10, 2010, 3:41 PM), http://www.fiercewireless.com/story/uscellular-plans-lte-test-vendor-selection-next-year/2010-11-10?utm_medium\%3Dr ss.26utm _ source\%3Drss.

140. Maisie Ramsay, U.S. Cellular Plans Major LTE Launch Before 2011 Holidays, WiRELESS WEEK (May, 9, 2011), http://www.wirelessweek.com/News/2011/05/CarriersLTE-Launch-2011-Holidays-US-Cellular/.

141. Id.

142. 14th Wireless Report, supra note 1, at para 29. Cellular South also serves parts of Alabama, Arkansas, Florida, Georgia, Kentucky, Louisiana, Tennessee, and Virginia. See Application of AT\&T Mobility Spectrum LLC and Qualcomm Inc, Petition to Deny of Cellular South, Inc., DA 11-252 WT Docket. No. 11-18, File No. 00045668251 (Mar. 11, 
880,000 subscribers, ${ }^{143}$ and it offers low-cost nationwide plans. ${ }^{144}$ Cellular South operates a CDMA-based network, and it has announced plans to deploy LTE in the fourth quarter of 2011. ${ }^{145}$ The company also recently purchased $700 \mathrm{MHz}$ spectrum, which should allow it to expand its service to all of Mississippi, Tennessee, and Alabama. ${ }^{146}$ Cellular South's acquisition of this spectrum places the company in an excellent position to compete with larger competitors in the southeastern part of the United States.

The 15th Wireless Report recognizes Atlantic Tele-Network (“ATN”) as a "new entrant in the U.S. mobile wireless retail services marketplace." ${ }^{147}$ Formed via the acquisition of twenty-six of the divestiture markets from the Verizon-Alltel transaction in April 2010, ATN offers wireless voice and data services under the Alltel name in rural markets located principally in the Southeast and Midwest. ${ }^{148}$ The report notes that as of June 2010, ATN had approximately 807,000 subscribers, "making them the ninth largest mobile wireless facilities-based provider, with a network footprint covering approximately six million POPs."149

\section{MARKET STRUCTURE ANALYSIS PRESUMES A STRICT RELATIONSHIP BETWEEN PRICES AND NUMBER OF PROVIDERS}

Ignoring the direct evidence of the lack of market power, the 14th and 15 th Wireless Reports rely heavily on a market-structure analysis in

2011) [hereinafter Petition to Deny of Cellular South], available at http://fjallfoss.fcc.gov/ecfs/document/view?id=7021034266.

143. Petition to Deny of Cellular South, supra note 142, at 1.

144. Why Cellular South?, CellularSouth.COM, http://web.archive.org/web/201012 26022639/http://www.cellularsouth.com/DiscoverCenter/why-cs/att.jsp (last visited Feb. 20, 2012) ("Our Smartphone Unlimited Plan is a first-of-its-kind value! Get unlimited talk, text, email, and web at a price that saves you over $\$ 40 /$ month compared to AT\&T or Verizon. That's more than $\$ 480$ /year!').

145. History/Timeline, CellularSouth.com, http://web.archive.org/web/2010021100 3136/http://www.cellularsouth.com/aboutus/History-Timeline.html (last visited Feb. 20, 2012); Press Release, Cellular Wireless, Cellular South Announces Strategic Alliance with Samsung Telecommunications to Build LTE 4G High-Speed Wireless Broadband Data Network Infrastructure (Nov. 17, 2010), http://www.businesswire.com/news/home/2010 $1117006651 /$ en/Cellular-South-Announces-Strategic-Alliance-Samsung-

Telecommunications.

146. About Us, CELlularSouth.COM, http://web.archive.org/web/20101005034437/ http://www.cellularsouth.com/aboutus/index.html (last visited Feb. 20, 2012) ("We've invested more than $\$ 530$ million in network infrastructure since 2006 to activate over 500 new cell sites, including nearly 450 completely new sites with $3 \mathrm{G}$ high-speed data capacity.").

147. 15th Wireless Report, supra note 4, at para. 71.

148. Id.

149. Id. (footnote omitted). 
refraining from declaring the wireless industry is effectively competitive. Given the highly differentiated product offerings in U.S. wireless markets, however, there is little basis to presume such a relationship. The structureconduct paradigm grows out of the Cournot model ${ }^{150}$ which assumes that firms compete by choosing the level of output (as opposed to prices), and that all firms' products are homogenous (as opposed to being differentiated). Although more elaborate versions of the model accommodate other forms of competitive interaction, the relationship between price-cost markup and industry concentration (the HHI) is more established under the homogenous products assumption. Indeed, when this relationship between market structure and price-cost margin is derived in the seminal textbook on industrial organization, the authors make the simplifying assumption that "[a]n oligopoly consists of $n$ identical firms that produce a homogenous product." ${ }^{51}$ As Carl Shapiro, the Deputy Assistant Attorney General for Economic Analysis at the Department of Justice explains:

For homogeneous products, the traditional structural approach of defining markets and measuring market shares and market concentration has deep roots, along with a rich empirical tradition linking market structure to performance. In these markets, it is both natural and appropriate to count up each firm's unit or dollar sales, or capacity, to measure market shares, and to make inferences about a merger's effects based on market structure, including the HHI of market concentration. The danger of collusion is surely related to market concentration (although quantifying this relationship is difficult), and economists' primary model of non-cooperative oligopolistic competition among manufacturers of homogeneous goods [the Cournot model] relates market structure to performance. Although economists continue to debate the empirical relationship between market structure and performance, there exists a solid foundation for using market structure prominently in evaluating horizontal mergers involving homogeneous goods. This traditional structural approach towards merger policy, which dates back to the 1960s but has been refined as just described, is less attractive for differentiated products. When products are highly differentiated, concerns about coordinated effects may be secondary to concerns about unilateral effects. And, to assess unilateral effects most accurately, it is highly desirable to go beyond industry concentration measures to look directly at the extent of competition between the merging brands. This is especially true if competition is "localized,"

150. $C f$. Timothy F. Bresnahan, Empirical Studies of Industries with Market Power, in 2 HANDBOOK OF INDUSTRIAL ORGANIZATION 1011 (Richard Schmalensee \& Robert Willig eds., 1989).

151. Dennis W. Carlton \& Jeffrey M. Perloff, Modern Industrial Organization 283 (4th ed. 2005) (emphasis added). 
i.e., if some brands are especially close substitutes for other brands due to their product characteristics or image.

Yet, the wireless marketplace clearly does not operate like this highly simplified textbook model. Competition in wireless markets occurs along several dimensions. Carriers differentiate themselves using varied pricing structures (for example, free in-network calling), service quality, and devices. ${ }^{153}$ When the homogenous products assumption is violated, the predictions of the structure-conduct paradigm are often unreliable.

In its 14th and 15th Wireless Reports, the FCC did not offer any evidence of a structure-conduct relationship, though the organization of the reports clearly supposes that such a relationship exists. ${ }^{154}$ In particular, the structure-conduct relationship does not appear to hold across the relevant range of carriers today-namely, four-to-six carriers per market. As demonstrated in Figure 1 (above), the inverse relationship between market structure and conduct from 2003 through 2009 is the opposite of what is predicted under the structure-conduct paradigm. Sections III of both reports discuss industry structure, while Sections IV of both reports discuss industry conduct, yet there is no discussion of the relationship between the two sections. ${ }^{155}$ The lack of a bridge between the two sections indicates that the FCC has not endeavored to bolster this structure-conduct assumption. In applying a standard market structure analysis to a dynamic,

152. Carl Shapiro, Mergers with Differentiated Products, ANTITRust, Spring 1996, at 23 (emphasis added).

153. The FCC explains the degree of product differentiation in the Twelfth CMRS Report. Annual Report and Analysis of Competitive Market Conditions with Respect to Commercial Mobile Services, Twelfth Report, 23 F.C.C.R. 2241, para. 112 (2008) ("The continued rollout of differentiated pricing plans also indicates a competitive marketplace. In the mobile telephone sector, we observe independent pricing behavior, in the form of continued experimentation with varying pricing levels and structures, for varying service packages, with various handsets and policies on handset pricing. Today all of the nationwide operators, and many smaller operators, offer some version of a national rate pricing plan in which customers can purchase a bucket of minutes to use on a nationwide or nearly nationwide network without incurring roaming or long-distance charges.").

154. T. Randolph Beard, George S. Ford, Lawrence J. Spiwak \& Michael Stern, A Policy Framework for Spectrum Allocation in Mobile Communications, 63 FED. Comm. L.J. 639, 639-666 (2011), http://www.law.indiana.edu/fclj/pubs/v63/no3/Vol.63-3_2011-May_Art.03_Beard.pdf ("While the PCS auctions in the mid-1990s broke the then (governmentcreated) duopolistic market, over the past decade the amount of spectrum allocated to commercial services has risen substantially; at the same time, however, industry concentration has risen slightly as mobile communications advances toward an equilibrium market structure.").

155. Section III of the 14th Wireless Report is titled "Mobile Wireless Services: Industry Structure," while Section IV is titled "Mobile Wireless Services: Provider Conduct." 14th Wireless Report, supra note 1, at 11407. The 15th Wireless Report has the same organizational structure. 
technologically advanced, and differentiated product such as wireless services, the FCC is trying to put a square peg into a round hole.

The number of wireless providers varies by local market, which will affect local concentration measures. Leap and MetroPCS are quickly expanding their respective footprints, and each often represents the fifth national carrier in a local given market after Verizon, Sprint, AT\&T, and TMobile. ${ }^{156}$ Of the top twenty-five U.S. wireless markets, both Leap and MetroPCS have entered two markets-Philadelphia and Detroit—bringing the total number of national carriers to six in those markets. ${ }^{157}$ In another four of the top twenty-five wireless markets-Seattle, Minneapolis, Cleveland, and Indianapolis-wireless customers have only four nationwide providers - that is, neither Leap nor MetroPCS has entered the market. ${ }^{158}$ In the remaining nineteen markets (equal to twenty-five less six), either Leap or MetroPCS has entered. ${ }^{159}$ Another source of local variation is the presence of regional carriers such as U.S. Cellular, Cellular South, and ATN. ${ }^{160}$

It is theoretically possible that the four national carriers offer targeted discounts to customers living in local markets in which their market shares are relatively low (a potential indicator of the lack of local competition); if this is the case, then the wireless bills would reflect these targeted discounts. To test this structure-conduct hypothesis, we examined wireless billing data from TNS Telecoms. ${ }^{161}$ The database tracks telecomatlconsumption on a continuous basis for thousands of U.S. households, including the usage of local, long distance, and wireless telephone, cable and satellite television, and Internet service every quarter. TNS Telecoms combines bill data with extensive demographic information such as age, income, education, family status, occupation, ownership and size of household.

A common measure of market structure is the HHI of a given local area. In its 14th Wireless Report, the FCC reported HHIs for 172 economic

156. Dan Butcher, Leap Wireless Seeks Funding for Market Expansion, MoBILE MARKETER (Jun. 20, 2008), http://www.mobilemarketer.com/cms/news/carriernetworks/1194.html ("While Cricket originally was a spinoff of Qualcomm that served primarily smaller, rural markets, the company now operates in 23 states. The company owns spectrum licenses for 35 of the top 50 markets, such as Chicago, Milwaukee, Minneapolis, Philadelphia, Washington, Baltimore, New Orleans and Seattle.”).

157. See infra sec. V tbl.3.

158. Id.

159. Id.

160. Id.

161. TNS, TNS Telecoms Bill Harvesting, http://www.tnstelecoms.com/billharvesting. html (last visited Feb. 20, 2012). 
areas in $2008 .{ }^{162}$ We analyzed the variation in total monthly wireless bills across all households in the TNS database from the first quarter of 2008 through the third quarter of 2008. In particular, we regressed the total bill for a household on: (1) a dummy for the customer's wireless provider; (2) a dummy for the state; (3) the age of the respondent; (4) the income of the household; (5) whether the handset is used to access the Internet; (6) whether the handset is used for text messaging; (7) whether the handset is used to access email; (8) whether a child away from the home has a wireless phone; (9) the number of prepaid wireless accounts; (10) the total number of cell lines in the household; (11) the number of months left on the wireless contracts; and (12) the HHI of the economic area in which the household resides. Under the structure-conduct hypothesis, the coefficient on HHI should be positive and statistically significant. Table 2 shows the results.

162. 14th Wireless Report, supra note 1, at 11644-47 tbl.C-3. These data were updated for 2009 in the 15th Wireless Report. 15th Wireless Report, supra note 4, at 9697 tbl.C-3. 
TABLE 2: REgRESSION OUTPUT (DEPENDENT VARIABLE: TOTAL MONTHLY BILL) ${ }^{163}$

\begin{tabular}{|c|c|c|c|c|c|c|}
\hline & \multicolumn{3}{|c|}{ HHI Regression } & \multicolumn{3}{|c|}{ Leap/MetroPCS Regression } \\
\hline Variable & Coefficient & Std. error & $\mathbf{p}$ & Coefficient & $\begin{array}{l}\text { Std. } \\
\text { error }\end{array}$ & $\mathbf{p}$ \\
\hline Age of respondent & $-.1803545^{*}$ & 0.03 & 0.00 & $-.1520583 *$ & 0.02 & 0.00 \\
\hline Midpoint of income ranges & $-.0000407 *$ & 0.00 & 0.00 & $-.0000416^{*}$ & 0.00 & 0.00 \\
\hline $\begin{array}{l}\text { Use wireless phone for } \\
\text { wireless web }\end{array}$ & $9.524243 *$ & 1.22 & 0.00 & $10.17544 *$ & 1.08 & 0.00 \\
\hline $\begin{array}{l}\text { Use wireless phone for text } \\
\text { messaging }\end{array}$ & $10.11118^{*}$ & 0.81 & 0.00 & $10.10933^{*}$ & 0.70 & 0.00 \\
\hline Use wireless phone for e-mail & $8.26061^{*}$ & 1.16 & 0.00 & $7.678402 *$ & 1.03 & 0.00 \\
\hline $\begin{array}{l}\text { Child away from home has a } \\
\text { wireless phone }\end{array}$ & $3.992265 * *$ & 1.59 & 0.01 & $3.602429 *$ & 1.37 & 0.01 \\
\hline $\begin{array}{l}\text { Number of prepaid wireless } \\
\text { accounts }\end{array}$ & 0.50 & 1.08 & 0.64 & 0.83 & 0.96 & 0.39 \\
\hline $\begin{array}{l}\text { Total number of cellular lines } \\
\text { in household }\end{array}$ & $38.79829 *$ & 0.37 & 0.00 & $38.4376^{*}$ & 0.32 & 0.00 \\
\hline $\begin{array}{l}\text { Number of months left on } \\
\text { wireless contract }\end{array}$ & $.1772952 *$ & 0.06 & 0.00 & $.1628021 *$ & 0.05 & 0.00 \\
\hline$H H I$ & -0.000174 & 0.00 & 0.86 & $\mathrm{NA}$ & & \\
\hline Leap market & NA & & & 1.4408 & 0.93 & 0.12 \\
\hline MetroPCS market & NA & & & $2.82274 * *$ & 1.34 & 0.04 \\
\hline Carrier $=$ Sprint & $3.610493 *$ & 1.35 & 0.01 & $3.366204 *$ & 1.21 & 0.01 \\
\hline Carrier $=A T \& T$ & $3.228713 *$ & 1.15 & 0.00 & $2.621129 * *$ & 1.03 & 0.01 \\
\hline Carrier $=$ Verizon & $4.188472 *$ & 1.15 & 0.00 & $4.125661^{*}$ & 1.03 & 0.00 \\
\hline Constant & 6.17 & 15.12 & 0.68 & 8.75 & 9.74 & 0.37 \\
\hline
\end{tabular}

As Table 2 shows, age of the household (lower bill), household income (lower bill), text messaging (higher bill), Internet use (higher bill), email use (higher bill), a child away from home on the account (higher bill), and the number of lines in the household (higher bill) have the expected sign. The carrier coefficients are positive and statistically significant, suggesting that T-Mobile (the omitted carrier) offers a slight discount relative to Verizon, AT\&T, and Sprint. More importantly, the HHI coefficient is slightly negative (the opposite of what is predicted under the structure-conduct paradigm) and not statistically different from zero, indicating that wireless carriers do not alter their prices with local concentration levels. ${ }^{164}$ This finding is entirely inconsistent with the

163. Notes: * Statistically Significant at 1 percent level; ** Statistically Significant at 10 percent level. State dummies omitted from table. First specification: $\mathrm{N}=7,681 ; \mathrm{R}$ squared $=$ 0.67. Second specification: $N=9,739 ; \mathrm{R}$ squared $=0.68$. Missing values for certain TNS fields were replaced with average values.

164. As recognized in the 15th Wireless Report, from the customer's perspective, the 
structure-conduct hypothesis that undergirds the FCC's market share analysis. As demonstrated in Appendix 2, our finding is robust to the regression specification. ${ }^{165}$

Finally, to further test the structure-conduct hypothesis, we replaced the HHI variable in the above regression with dummies for Leap or MetroPCS markets. A market was designated as a Leap (or MetroPCS) market if at any time in the TNS sample data there was a bill from a Leap customer living in the area. Because we recovered observations for which there was no HHI data from the FCC, the sample expanded from 7,681 to 9,739. As Table 2 shows, the coefficients on Leap and MetroPCS markets are slightly positive (the MetroPCS market dummy is statistically significant), again undermining the hypothesis that the market structure (at least over the current range of four to six carriers) affects prices. This analysis undermines the fundamental premise of the FCC's market structure analysis-namely, that market structure is a predictor for market performance.

Even assuming counterfactually that a relationship exists between market structure and pricing, the wireless market is not conducive to the exercise of market power. Competition in most markets, by the FCC's own calculation, is strong. The 14th Wireless Report estimates that 91.3 percent of the U.S. population lives in census blocks served by four or more mobile operators. ${ }^{166}$ In comparison, 65.5 percent of the rural population lives in census blocks with at least four competing mobile voice operators. ${ }^{167}$ The 15th Wireless Report estimated that the percentage of the U.S. population in 2010 that could choose from five or more providers of mobile voice services was 89.6 percent, up from 72.8 percent in $2009 .{ }^{168}$ The report also notes that the percentage of the U.S. population in 2010 that could choose from four or more wireless broadband providers was 67.8 percent, up from 58 percent in 2009 . $^{169}$

Further, the U.S. wireless market has a lower HHI than other developed countries in Europe and Asia. To defend its (outdated) approach,

choice of carrier occurs at the local level, regardless of the pricing strategies of the carriers. 15th Wireless Report, supra note 4, para. 47 n. 117 ("The Commission typically evaluates the competitive effects of transactions involving mobile wireless licenses at the CMA level because that is the relevant geographic market for most consumers. Consumers generally search for service providers in the local areas where they live, work, and travel and are unlikely to search for providers that do not serve their local areas.").

165. See infra app. 2.

166. 14th Wireless Report, supra note 1, at para. 45.

167. Id. at 11427.

168. 15th Wireless Report, supra note 4, at 9705 tbl.5.

169. Id. at 9706 tbl. 7. See also 14th Wireless Report, supra note 1, at 11450 tbl.7. 
the FCC argues that these nationwide concentration indices understate the true amount of concentration because the appropriate unit of observation is sub-national. ${ }^{170}$ Setting aside the inherent problems of inferences based on market shares, ${ }^{171}$ enhanced competition often comes in the form of regional carriers as well as national carriers. U.S. Cellular and Cellular South have a strong presence in the markets they serve. Because national carriers such as Leap and MetroPCS are entering local markets in a staggered fashion, certain local markets will exhibit less concentration than the national average.

Table 3, below, shows the number of unique wireless providers by market for the top twenty-five U.S. wireless markets. The table does not include the more than sixty mobile virtual network operators that resell service in these markets.

170. 14th Wireless Report, supra note 1, at para. 364.

171. The U.S. HHIs are less than all the comparable countries listed by the FCC, including the United Kingdom, Germany, Italy, Canada, Australia, Sweden, France, Finland, and Japan. Even using the adjusted HHI proposed by the FCC of 2,848, only the UK would have a lower HHI. See id. at 11621 tbl.41. 
Table 3: Number of Unique Wireless Providers, by Market ${ }^{172}$

\begin{tabular}{|c|c|c|c|c|}
\hline Rank & Market & $\begin{array}{c}\text { \# of Unique } \\
\text { Nationals }\end{array}$ & $\begin{array}{l}\text { \# of Unique } \\
\text { Regionals }\end{array}$ & $\begin{array}{c}\text { Total \# of } \\
\text { Unique } \\
\text { Carriers }\end{array}$ \\
\hline 1 & New York, NY & 5 (MetroPCS) & & 5 \\
\hline 2 & Los Angeles, CA & 5 (MetroPCS) & & 5 \\
\hline 3 & Chicago, IL & 5 (Leap) & 1 (U.S. Cellular) & 6 \\
\hline 4 & Philadelphia, PA & $\begin{array}{c}6 \text { (MetroPCS, } \\
\text { Leap) }\end{array}$ & & 6 \\
\hline 5 & Dallas, TX & 5 (MetroPCS) & & 5 \\
\hline 6 & San Francisco, CA & 5 (MetroPCS) & & 5 \\
\hline 7 & Boston, MA & 5 (MetroPCS) & & 5 \\
\hline 8 & Atlanta, GA & 5 (MetroPCS) & & 5 \\
\hline 9 & Washington, DC & 5 (Leap) & & 5 \\
\hline 10 & Houston, TX & 5 (Leap) & & 5 \\
\hline 11 & Detroit, MI & $\begin{array}{l}6 \text { (MetroPCS, } \\
\text { Leap) }\end{array}$ & & 6 \\
\hline 12 & Phoenix, AZ & 5 (Leap) & & 5 \\
\hline 13 & Seattle, WA & 4 & & 4 \\
\hline 14 & Tampa, FL & 5 (MetroPCS) & & 5 \\
\hline 15 & Minneapolis, MN & 4 & 1 (U.S. Cellular) & 5 \\
\hline 16 & Denver, CO & 5 (Leap) & & 5 \\
\hline 17 & Miami, FL & 5 (MetroPCS) & & 5 \\
\hline 18 & Cleveland, $\mathrm{OH}$ & 4 & & 4 \\
\hline 19 & Orlando, FL & 5 (MetroPCS) & & 5 \\
\hline 20 & Sacramento, CA & 5 (MetroPCS) & & 5 \\
\hline 21 & St. Louis, MO & 5 (Leap) & 1 (U.S. Cellular) & 6 \\
\hline 22 & Portland, OR & 5 (Leap) & & 5 \\
\hline 23 & Pittsburgh, PA & 5 (Leap) & & 5 \\
\hline 24 & Charlotte, NC & 5 (Leap) & & 5 \\
\hline 25 & Indianapolis, IN & 4 & & 4 \\
\hline AVERAGE & & 4.92 & & 5.04 \\
\hline
\end{tabular}

Based on our survey, U.S. consumers in the top twenty-five markets have on average 4.92 unique providers offering national service ("national providers"); two markets have six national providers, four other markets have four national providers, and the rest have five. Three of the top

172. Note that the first four carriers in each market are Verizon, AT\&T, Sprint Nextel, and T-Mobile. The counts for regional networks do not include ATN because public data on ATN's coverage area is not sufficiently specific. See ATN, Our Network, ATLANTIC TEleNETWORK, http://www.atni.com/network.html (last visited Feb. 20, 2012). 
twenty-five markets also have a Super Regional carrier (U.S. Cellular), bringing the average number of unique providers including Super Regionals to 5.04. (As Table 2 shows, the coefficients on Leap and MetroPCS markets are not negative and significant, as predicted by the structure-conduct hypothesis, suggesting that wireless consumers in those markets do not receive lower prices than the rest of the nation). Even if there was a relationship between market concentration and prices for some level of providers, the large number of unique providers in each market suggests that the relationship no longer holds over the relevant range of providers. Stated differently, while a movement from one-to-two or two-tothree carriers in a local market might significantly affect prices, the movement from four-to-five carriers does not appear to be important based on our regression results above.

\section{VERIZON AND AT\&T DO NOT APPEAR TO POSSESS A "MUST-HAVE" INPUT}

The 14th Wireless Report intimates that spectrum below-1000 MHz is a must-have input for a carrier to compete effectively. ${ }^{173}$ Similarly, the 15th Wireless Report devotes a section to analyzing spectrum holdings below-1000 MHz. ${ }^{174}$ The major difference between below-1000 MHz spectrum and above- $1000 \mathrm{MHz}$ spectrum is the cost of deployment. As explained by the FCC, "[a] licensee that exclusively or primarily holds spectrum in a higher frequency range generally must construct more cell sites (at additional cost) than a licensee with primary holdings at a lower frequency in order to provide equivalent service coverage, particularly in rural areas." 175

The FCC explains that although Sprint Nextel and T-Mobile have some spectrum below the $1000 \mathrm{MHz}$ threshold, AT\&T and Verizon have significant holdings of this must-have input, ${ }^{176}$ allegedly giving AT\&T and Verizon a "competitive advantage." 177 The FCC would be hard-pressed to

173. Id. at paras. 268-71 ("Lower frequency bands - such as the $700 \mathrm{MHz}$ and Cellular bands - possess more favorable intrinsic spectrum propagation characteristics than spectrum in higher bands.").

174. 15th Wireless Report, supra note 4, at paras. 298-300.

175. Id. at para. 293 (citing a propagation model put forth by the National Institute of Standards and Technology, and a Okumara-Hata model).

176. Id. at para. 298 ("Three nationwide providers - Verizon Wireless, AT\&T, and Sprint Nextel - hold licenses for CMRS/mobile broadband spectrum below $1 \mathrm{GHz}$, as do regional providers, such as US Cellular and Cellular South, MetroPCS, and several smaller companies, many of which have holdings in more rural areas of the country. T-Mobile, the fourth nationwide provider, holds one Cellular license in South Carolina.").

177. Id. at para. 307 ("For instance, given the superior propagation characteristics of spectrum under $1 \mathrm{GHz}$, particularly for providing coverage in rural areas and for penetrating 
explain why Clearwire is purchasing spectrum above $1000 \mathrm{MHz}$ that is allegedly inferior. ${ }^{178}$

By narrowly defining the market this way, the FCC appears to be setting the stage for imposing a limit (sometimes called a cap) on spectrum that AT\&T and Verizon can acquire; otherwise, according to the FCC's theory, the wireless industry will not be competitively supplied. In this section, we explain that the FCC is contradicting a position it previously took on this matter, and that competitors value spectrum from different bands differently, suggesting that one type of spectrum can be substituted for another.

\section{A. The Nextel Re-Banding Process}

The FCC's current position that below-1000 MHz spectrum is a "must-have" input contradicts its previous view of the interchangeability of below-1000 MHz and above-1000 MHz spectrum in the Nextel re-banding case. There, the FCC determined that $1900 \mathrm{MHz}$ spectrum was suitable replacement spectrum for the $800 \mathrm{MHz}$ licenses given up by Nextel. In particular, the FCC concluded that spectrum in the $1900 \mathrm{MHz}$ band was "equitable compensation" for Nextel's 700 and $800 \mathrm{MHz}$ spectrum. ${ }^{179}$

In July 2004, the FCC put into effect a new band plan for the 800 $\mathrm{MHz}$ band to handle interference to public safety providers. ${ }^{180}$ The FCC determined that incompatible technologies between public safety providers operating in the $800 \mathrm{MHz}$ band and Nextel were causing the interference and that reconfiguration of the $800 \mathrm{MHz}$ and $700 \mathrm{MHz}$ band was necessary. ${ }^{181}$ The FCC required Nextel to give up rights to certain of its licenses in the $800 \mathrm{MHz}$ band and all of its licenses in the $700 \mathrm{MHz}$ band. ${ }^{182}$ In exchange, Nextel should be compensated for relinquishing its licenses in the 700 and $800 \mathrm{MHz}$ bands, as well as for paying for

buildings, providers whose spectrum assets include a greater amount of spectrum below 1 $\mathrm{GHz}$ spectrum may possess certain competitive advantages for providing robust coverage when compared to licensees whose portfolio is exclusively or primarily comprised of higher frequency spectrum.").

178. In the 15th Wireless Report, the FCC attributes Clearwire's spectrum holdings to Sprint, and it notes that Sprint and Clearwire together hold 47 percent of the MHz-POPs of the above-1000 MHz bands, which include PCS, AWS, BRS and EBS. Id. at 9682 n.19.

179. Improving Pub. Safety Comm. in the $800 \mathrm{MHz}$ Band, Report and Order, Fifth Report and Order, Fourth Memorandum Opinion and Order, and Order, 19 F.C.C.R. 14969, para. 211 (2004) [hereinafter $2004 R \& O$ ].

180. Implementation of Section 6002(b) of the Omnibus Budget Reconciliation Act of 1993, Eleventh Report, 21 F.C.C.R. 10947, para. 66 (2006) [hereinafter 11th CMRS Report].

181. $2004 R \& O$, supra note 179 , at para. 2 .

182. 11th CMRS Report, supra note 180, at para. 66. 
incumbent relocation costs. ${ }^{183}$ The FCC determined that this compensation should not be done on "megahertz-for-megahertz" basis, but instead "value-for-value" basis. ${ }^{184}$ Accordingly, the FCC modified Nextel's licenses to provide the right to operate on two five-MHz blocks in the 1900 MHz band. ${ }^{185}$ The FCC determined that the overall value of the $1900 \mathrm{MHz}$ spectrum was $\$ 4.8$ billion, less the cost of relocating incumbent users. ${ }^{186}$ The value of Nextel's average 4.5 MHz spectrum licenses in the $800 \mathrm{MHz}$ band was $\$ 1.607$ billion, but this figure was later amended to \$2.1 billion. $^{187}$

Throughout this proceeding, the selection of appropriate replacement spectrum for Nextel was debated thoroughly. The FCC ultimately agreed that $1900 \mathrm{MHz}$ spectrum was suitable replacement spectrum for the 800 MHz licenses given up by Nextel. The FCC ruled:

We conclude that it is in the public interest to compensate Nextel for the surrendered spectrum rights and costs it will incur as a result of band reconfiguration. . . . In light of these substantial public interest benefits, we conclude that it is appropriate for Nextel to receive equitable compensation in the form of spectrum rights to the 1910$1915 \mathrm{MHz}$ and 1990-1995 MHz bands .... 188

This result came after several parties, most notably Verizon, argued that Nextel would receive spectrum in the $1900 \mathrm{MHz}$ band that was more valuable than the spectrum in the $800 \mathrm{MHz}$ band. ${ }^{189}$ Indeed, Verizon argued that if Nextel received spectrum in the $1900 \mathrm{MHz}$ band, then Verizon would challenge the award in court. ${ }^{190}$ Nextel wanted the 1900 $\mathrm{MHz}$ spectrum and stated that they would not accept spectrum in the 2100 MHz band instead. ${ }^{191}$ That the FCC and Nextel perceived the $1900 \mathrm{MHz}$

183. $2004 R \& O$, supra note 179 , at paras. 210, 211, 217 ("We find that providing replacement spectrum rights for Nextel is a sine qua non for elimination of unacceptable interference in the $800 \mathrm{MHz}$ band."). Id. at para. 217.

184. Id. at para. 32 .

185. Id. at para. 33 .

186. 11th CMRS Report, supra note 180, at para. 66 .

187. $2004 R \& O$, supra note 179 , at para. 35 . The figure was originally reported to be $\$ 1.607$ billion, but later was amended. Improving Pub. Safety Comm. in the $800 \mathrm{MHz}$ Band, Supplemental Order and Order on Reconsideration, 19 F.C.C.R. 25120, paras. 27-28 (2004). To be fair, the $800 \mathrm{MHz}$ spectrum was partitioned by locality, whereas the 1900 $\mathrm{MHz}$ spectrum was contiguous and national. Because contiguous spectrum is more valuable than local spectrum, a full comparison of the relative values is complicated.

188. $2004 R \& O$, supra note 179 , at para. 211.

189. Id. at para. 210 ("Other parties contend that the value of the spectrum rights Nextel seeks substantially exceeds the value of the spectrum rights it has offered to give up, and therefore would constitute an unwarranted windfall to Nextel.").

190. Donny Jackson, Nextel Sweetens Consensus Plan, Urgent Comm. (July 1, 2004, 12:00 PM), http://urgentcomm.com/mag/radio_nextel_sweetens_consensus/.

191. Id. 
spectrum licenses to be suitable replacements for Nextel's 700 and 800 MHz spectrum suggests that above- 1000 and below- $1000 \mathrm{MHz}$ spectrum is at least partially fungible.

\section{B. Spectrum Is One of Several Inputs in the Production Process}

In the 14th Wireless Report, the FCC based its claim that below-1000 $\mathrm{MHz}$ is more valuable on the relative prices paid by wireless providers for the two bands in recent auctions. The FCC explains:

The recent auctions of AWS and $700 \mathrm{MHz}$ spectrum (Auctions 66 and 73 , respectively) provide a basis for comparison, as both auctions involved large quantities of paired spectrum in a relatively close timeframe. In the 2008 auction of $700 \mathrm{MHz}$ spectrum, the average price for the $700 \mathrm{MHz}$ spectrum was $\$ 1.28$ per MHz-pop. This unit price was more than twice the average price of $\$ 0.54$ per MHz-pop for AWS spectrum [at 1700 and $2100 \mathrm{MHz}$ ] auctioned in 2006.

Given that the FCC previously noted that the cost of deploying higher frequency spectrum exceeded the cost of deploying lower frequency spectrum, the resultant price differential of this spectrum-a complementary input in the product process-is expected. Providers pay more upfront for low-frequency spectrum but less on the deployment end. The opposite is true for providers who purchase high-frequency spectrum. In the end, the total buildout cost should balance out; otherwise, there would be room for arbitrage. If anything, the FCC's evidence of lower prices in the above- $1000 \mathrm{MHz}$ spectrum suggests that carriers that purchase such spectrum will not incur higher buildout costs, so long as buildout costs are properly defined to include both spectrum costs and deployment costs.

\section{The Requisite Level of Spectrum Below-1000 MHz}

The FCC's analysis of the concentration of spectrum holdings below $1000 \mathrm{MHz}$ is slightly misleading. Incremental sub-1000 MHz spectrum at any level does not always mean a significantly better product or improved performance. Indeed, a combination of above-1000 MHz spectrum and a small amount of below-1000 MHz spectrum can provide for effective performance. Ofcom, the FCC's counterpart in Europe, explained this phenomenon in their rules for their forthcoming spectrum auction:

[A] multi-frequency network combining $2 \times 5 \mathrm{MHz}$ of $800 \mathrm{MHz}$ spectrum (operated at $15 \%$ loading) with $2 \times 20 \mathrm{MHz}$ of $2.6 \mathrm{GHz}$ spectrum (operated at $85 \%$ loading) can on all measures, all but match,

192. 14th Wireless Report, supra note 1, at para. 271 n.4. "'MHz-POPs' refers to the amount of spectrum in a given license or set of frequencies multiplied by the population covered by the geographic area of the spectrum license." $I d$. 
or even better, the performance of a network using $2 \times 15 \mathrm{MHz}$ of 800 $\mathrm{MHz}$ spectrum alone (operated at $85 \%$ loading).

Indeed, the FCC itself acknowledges that a combination of highfrequency and low-frequency spectrum can be valuable in offering competitive wireless service and that the mix of spectrum holdings is likely more important than absolute holdings. ${ }^{194}$

Finally, in the 15th Wireless Report, the FCC explains that the Mobile Satellite Service ("MSS") industry is "undergoing major technological and structural changes," which will allow MSS providers to offer broadband services that "could potentially enhance competition in the provision of terrestrial mobile wireless services." 195 The report also notes that "the Commission is taking steps to make additional MSS spectrum available for new investment in mobile broadband networks ...."196 To the extent that MSS spectrum is fungible with spectrum in other frequency bands (like Cellular or $700 \mathrm{MHz}$ ) that support wireless broadband, it makes little sense to draw arbitrary lines around "good" spectrum as a way to determine a carrier's market power.

As we explain below in the section on policy, the best solution to any perceived competition problem is to get more spectrum into the market and to ensure that companies like Sprint Nextel, Leap, MetroPCS, Cellular South, and other new entrants that have not yet surfaced have access to that spectrum. Ofcom is seeking consultation for an upcoming auction (slated for 2012) in which it could package small amounts of lower frequency spectrum with larger amounts of higher frequency spectrum. If the FCC should deem below-1000 MHz spectrum to be uniquely advantageous, it can achieve the same goals by also packaging some below-1000 $\mathrm{MHz}$ spectrum with above-1000 MHz spectrum. But even this is likely

193. Ofcom, Consultation on Assessment of Future Mobile Competition and Proposals FOR THE AwARd FOR $800 \mathrm{MHz}$ AND 2.6 GHz SPECTRUM AND Related Issues: ANNEXES 7-13, 29 (2011) (emphasis added).

194. 14th Wireless Report, supra note 1, at para. 273 ("Some analysts also have observed that there can be important complementarities that come with holding spectrum assets in different frequency bands, noting that combination of sub-1 $\mathrm{GHz}$ and higher frequency spectrum may be optimal. For example, low frequency spectrum can be deployed ubiquitously with relatively few cell sites, providing a base layer of coverage that extends to wide areas in rural America as well as deep into buildings in urban areas. However, in urban areas where traffic concentration is high, this base coverage layer may be complemented with a capacity layer using high frequency spectrum. In this sense, higher-frequency spectrum is made more valuable by being combined with lower-frequency spectrum, and vice versa. Given these different spectrum characteristics, a licensee's particular mix of spectrum holdings may affect its ability to provide efficient mobile wireless services.").

195. 15th Wireless Report, supra note 4, at para. 39.

196. Id. at 9825 n.799. 
unnecessary; in prior auctions, including the $700 \mathrm{MHz}$ auction, significant amounts of below-1000 MHz spectrum were obtained by entrants. ${ }^{197}$

\section{ARE We MisSING SOMETHING?}

Economists recently have been criticized for fixating on price effects. ${ }^{198}$ Although consolidation might bring about lower prices through economies of scale and scope, the argument goes, innovation could be sacrificed if upstream inputs (in this case, handsets or applications) are foreclosed from rivals. While plausible as a matter of theory, the FCC has not offered any evidence that this risk is likely in the wireless industry. Indeed, the FCC's report chronicles several developments that suggest that innovation among carriers and application providers (review below) is rapidly advancing.

Innovation at the core of the network does not appear to be stagnating. With the exception of T-Mobile, the national carriers are investing in LTE technology $y^{200}$ and deploying $4 \mathrm{G}$ services, which will offer peak data speeds at nearly ten times the speeds for $3 \mathrm{G}$ service. For example, LTE deployments are expanding rapidly, with Verizon Wireless covering thirtynine cities and MetroPCS covering thirty cities by the end of 2010. AT\&T, Cellular South, and LightSquared each have planned LTE rollouts in 2011, and U.S. Cellular plans a rollout of LTE in 2012. In addition to LTE deployments, several carriers are introducing WiMax throughout the nation, including Clearwire (in major markets), Digital Bridge (small to medium markets), and Clearwire/Sprint (seventy-one markets). According to CTIA's Semi-Annual Wireless Survey, the wireless carriers have

197. Statement from Kevin J. Martin, Chairman, FCC, Statement (March 20, 2008), http://hraunfoss.fcc.gov/edocs_public/attachmatch/DOC-280968A1.pdf (“A bidder other than a nationwide incumbent won a license in every market. As a result of the $700 \mathrm{MHz}$ Auction, there is the potential for an additional wireless "third-pipe" [sic] in every market across the nation. Additionally, 99 bidders, other than the nationwide wireless incumbents, won 754 licenses - representing approximately 69 percent of the 1090 licenses sold in the $700 \mathrm{MHz}$ auction. The Auction therefore drew wide-ranging interest from a number of new players. For example, Frontier Wireless LLC (EchoStar), which is widely viewed as a new entrant, won 168 licenses in the E block to establish a near nationwide footprint for its services for consumers.").

198. Tim Wu, Master Switch: The Rise and Fall of Information Empires 165 (2010) (criticizing Robert Crandall for focusing narrowly on the price effects of the Paramount decree).

199. 14th Wireless Report, supra note 1, at 11498 chart 8.

200. The 15th Wireless Report finds that five carriers had deployed or announced plans to deploy a LTE or WiMAX network by year-end 2010 or early 2011: Verizon Wireless, AT\&T, Sprint, Clearwire and MetroPCS. 15th Wireless Report, supra note 4, at 9735 tbl. 11. This does not include additional carriers with announced LTE plans, including Leap, U.S. Cellular, Cell South and LightSquared. With regard to T-Mobile, the report states "No U.S.-specific plans." Id. 
collectively invested nearly $\$ 300$ billion in cumulative capital expenditure. $^{201}$

Innovation at the edges of the network, including handsets and applications, is also proceeding at a rapid pace. According to CTIA, 630 devices are manufactured for the U.S. wireless market. ${ }^{202}$ Handset developments are described in greater detail in the policy section below. And innovation at the application layer suggests that wireless networks are not closed to independent content creators. Apple's app store alone boasted 500,000 applications for the iPhone as of January 2012. ${ }^{203}$ Although there are some notable cases in which Apple did not support an application that would displace the voice features of the iPhone (such as Google Voice), those choices were made by Apple and not by AT\&T. Applications and smartphones (along with netbooks and other wireless-enabled Internet access devices) are complements; the more compelling the applications, the greater the demand for the devices to access the applications. No amount of consolidation in the wireless industry should alter that calculus.

\section{POLICY IMPLICATIONS}

Further regulation and intervention by the FCC in the wireless services industry could have significantly adverse effects on investment, competition, and consumers in the wireless industry. As demonstrated above, wireless services are in fact competitively supplied. Consumers are facing historically low prices for both wireless voice and data, and they have unparalleled options for handsets and service providers. Although there are numerous policy implications from the 14th and 15th Wireless Reports, we focus here on handset exclusivity and spectrum policy.

\section{A. Handset Exclusivity}

The 14th and 15th Wireless Reports open the door for limiting handset exclusivity arrangements. For example, the 14th Wireless Report characterizes exclusive handset contracts as a barrier to entry that "can create a kind of adjustment cost for potential entrants if lack of access to the exclusive technology delays the entry of potential entrants." ${ }^{204}$ The 15 th Wireless Report uses nearly the same language. ${ }^{205}$ Empirically, the

201. Semi-Annual Wireless Industry Survey, CTIA (2011), http://files.ctia.org/pdf/ CTIA_Survey_MY_2011_Graphics.pdf.

202. 50 Wireless Quick Facts, CTIA ADVOCACY, http://www.ctia.org/advocacy/research/ index.cfm/AID/10378 (last visited Feb. 20, 2012).

203. iPhone, APPLE, INC., http://www.apple.com/iphone/apps-for-iphone/ (last visited Feb. 20, 2012).

204. 14th Wireless Report, supra note 1, at para. 66.

205. 15th Wireless Report, supra note 4, at para. 65 ("Exclusive handset arrangements 
FCC's argument has no basis, as entry into the wireless eco-system has been robust. To date, the FCC has correctly refrained from interfering in these arrangements.

Exclusivity agreements promote risk sharing in the launch of a new device, create incentives for marketing support for device manufacturers, and strengthen brand image through co-branding. They also compel manufacturers and carriers to innovate. For example, the iPhone's exclusivity agreement with AT\&T likely spurred the advent of Androidpowered phones on other carriers, such as Verizon, ${ }^{206}$ along with the Palm Pre and the BlackBerry Storm. ${ }^{207}$ Finally, exclusive agreements allow for more efficient financing terms. Because state-of-the-art handsets are expensive to make, it is difficult for manufacturers to finance customers' purchases. The financing of a handset is essentially an unsecured loan with a depreciating and difficult to repossess asset. Carriers can provide more efficient finance terms by bundling service (along with a locked phone) with the handset. Under this arrangement, there is greater certainty that the loan will be repaid; the certainty is even greater when the arrangement is exclusive.

Finally, exclusive handset agreements are commonly used in the wireless industry. A few notable examples include the Motorola Razr V3 (exclusive through AT\&T in 2004), ${ }^{208}$ the iPhone (exclusive through AT\&T until 2011), ${ }^{209}$ the BlackBerry Storm (exclusive through Verizon), ${ }^{210}$ the Palm Pre (exclusive through Sprint until 2009), ${ }^{211}$ and the

held by existing providers could potentially create an entry barrier if lack of access to the exclusive technology were to delay the entry of potential entrants.").

206. Gerald R. Faulhaber \& David J. Farber, Innovation in the Wireless Ecosystem: A Customer-Centric Framework, 4 INTL. J. CoMM. 73, 98 (2010); see also Matt Richtel, Google: Expect 18 Android Phones by Year's End, N.Y. Times Bits Blog (May 27, 2009, 7:20 P.M.), http://bits.blogs.nytimes.com/2009/05/27/google-expect-18-android-phones-byyears-end/.

207. Robert W. Hahn \& Hal J. Singer, Why the iPhone Won't Last Forever and What the Government Should Do to Promote Its Successor, 8 J. on Telecomm. \& High TeCH L. 313, 314 (2010); see also Stephen H. Wildstrom, Google's Android: Now a Contender, BLOOMBERG BusinessweEK (Jul. 22, 2009, 10:00 P.M.), http://www.businessweek.com/ magazine/content/09_31/b4141065675311.htm.

208. Roger O. Crockett, Cingular: Cool Phones Ring in a Merger, Bus. WK. (Oct. 26, 2004), http://www.businessweek.com/bwdaily/dnflash/oct2004/nf20041026_3765_db016 .htm.

209. Tony Bradley, R.I.P. iPhone Exclusivity, PC WorLd (Jan. 25, 2010, 9:31 AM), http://www.pcworld.com/businesscenter/article/187601/rip_iphone_exclusivity.html.

210. Sue Marek, RIM's Storm Will Be Exclusive on Verizon, Vodafone, FIERCEWIRELESS (Oct. 8, 2008, 8:31 AM), http://www.fiercewireless.com/story/verizon-vodafone-will-bothlaunch-rims-storm/2008-10-08.

211. Bonnie Cha, Sprint Has Palm Pre Exclusive Through 2009, CNET News (May 29, 2009, 9:02 AM), http://news.cnet.com/8301-17938_105-10252033-1.html. 
first Google phone powered by Android (exclusive through T-Mobile). ${ }^{212}$ When it launched its 4G services in 2011, MetroPCS promoted a 4Genabled Android smartphone by Samsung, ${ }^{213}$ the Galaxy Indulge that was not available through AT\&T, Verizon, Sprint, or T-Mobile. ${ }^{214}$ That entrants such as MetroPCS use exclusive handset arrangements suggests they are motivated by efficiency reasons.

\section{B. Spectrum Policy}

By any measure, the wireless industry is approaching a spectrum capacity crisis. Accordingly, policymakers need to get more spectrum into the market and allow licensees the right to buy, sell, and trade spectrum as they see fit. As long as the FCC fails to inject major amounts of spectrum into the marketplace, or strongly hints that future spectrum could be off limits to carriers with specific spectrum portfolios (below $1000 \mathrm{MHz}$ ), the agency leaves companies facing capacity shortages in the near term with no solution other than secondary market purchases or to raise retail prices. If regulators are opposed to consolidation as a means of addressing the spectrum crunch, then the remedy is not to deny a licensee the right to sell or trade their spectrum as they see fit, but rather to release more spectrum.

As suggested above, demand for wireless services has exploded. This increasing demand has unfortunately not been accompanied by increased spectrum access for providers. Up until this point, carriers have relied on core network innovation and increased efficiency to deal with increased traffic. ${ }^{215}$ The demand for spectrum, however, is only going to increase in the future as the consumer base for wireless services continues to grow and consumer preferences continue to trend toward smartphones.

How pressing is the need for spectrum? Consider the following: in early 2009, Cisco forecasted wireless data annual growth rates of nearly 140 percent, principally from the customer demand for handheld television. ${ }^{216}$ A June 2011 Cisco forecast placed the projected compound

212. Press Release, T-Mobile, T-Mobile Unveils the T-Mobile G1-the First Phone Powered by Android (Sept. 23, 2008), available at http://www.t-mobile.com/ company/PressReleases_Article.aspx?assetName=Prs_Prs_20080923\&title=TMobile\%20Unvei 1s\%20the \%20T-Mobile\%20G1\%20\%E2\%80\%93\%20the\%20First\%20Phone\%20Powered\%20 by $\% 20$ Android.

213. Press Release, MetroPCS, MetroPCS Launches 4G LTE Service in the Tampa Metropolitan Area (Apr. 1, 2011) (on file with MetroPCS Communications, Inc.).

214. Samsung Cell Phones: Samsung Galaxy Indulge QWERTY Cell Phone, SAMsung, http://www.samsung.com/us/mobile/cell-phones/SCH-R910ZKAMTR (last visited Feb. 20, 2012).

215. Faulhaber \& Farber, supra note 206, at 82.

216. Cisco, Cisco Visual Networking Index: Global Mobile Traffic Forecast UPDATE, 2011-2016 (2012), available at http://www.cisco.com/en/US/solutions/collateral 
annual growth rate for North America from 2010 to 2015 at 82 percent. $^{217}$ It bears noting that, like any forecast, the Cisco prediction could underestimate the amount of traffic that will be offloaded to Wi-Fi and other technologies, and it might not adequately consider the effects of more sophisticated rate plans that operators can use to shape traffic. The Cisco forecasts, along with more conservative forecasts by Coda and Yankee Group, are cited by the FCC. ${ }^{218}$

Engineering experts estimate that without FCC action, spectrum demand will exceed supply within the next few years, which means that without action, consumers will face more dropped calls and more expensive and slower service. ${ }^{219}$ It is only a matter of time before the innovative spectral efficiency employed by carriers will no longer be sufficient to meet growing customer needs. Chairman Genachowski acknowledged in a recent speech that there is a serious spectrum crunch, but he claimed that there is no need for industry consolidation to solve it. ${ }^{220}$ If that is the case, the FCC must execute the National Broadband Plan and release new spectrum imminently. Failure to do so could be catastrophic to the industry.

Ironically, the very entry barriers in the wireless marketplace cited by the FCC are partially its own creation. The 14th Wireless Report admits that "spectrum policies affect the ability of potential entrants to access spectrum and hence the technological, economic, and legal resources required to expand capacity." 221 The FCC also points the finger at local and state governments for tower-siting delays, stating that "delays in zoning approvals can lengthen the process of cell site acquisition and deployment, thereby increasing costs for new or existing providers to enter into new markets. ${ }^{222}$ Because spectrum and cell splitting (via additional towers) are substitutes, these entry barriers could be dissipated by more aggressive

/ns341/ns525/ns537/ns705/ns827/white_paper_c11-520862.html.

217. Cisco, Visual Networking Index: Forecast and Methodology 16 tbl.18 (2011), http://www.cisco.com/en/US/solutions/collateral/ns341/ns525/ns537/ns705/ns827/ white_paper_c11-481360.pdf.

218. FCC, Mobile Broadband: The Benefits of Additional Spectrum 9 (Oct. 2010), http://transition.fcc.gov/Daily_Releases/Daily_Business/2010/db1021/DOC-302324A1.pdf.

219. Peter Rysavy, The Spectrum Imperative: Mobile Broadband Spectrum and ITS IMPACTS FOR US CONSUMERS AND THE ECONOMY: AN ENGINEERING ANALYSIS 4 (2011) (estimating an approximate doubling of spectrum required over ten years to meet demand), available at http://www.rysavy.com/Articles/2011_03_Spectrum_Effects.pdf.

220. Jasmin Melvin, FCC Head Says Mergers Can't Solve Spectrum Crunch, REUTERS (Apr. 12, 2011, 10:39 PM), http://uk.reuters.com/article/2011/04/12/us-fcc-spectrummerger-idUKTRE73B7D020110412.

221. 14th Wireless Report, supra note 1, at para. 58.

222. Id. at para. 59 . 
spectrum allocation by the FCC (or more accommodating tower-siting policies by local governments).

Further, the FCC bemoans that wireless entrants face large aggregation costs because of the high cost of regional spectrum licenses:

For instance, in the two recent major spectrum auctions, the average spectrum price ranged from $\$ 0.53 / \mathrm{MHz} / \mathrm{Pop}$ for the AWS-1 (Advanced Wireless Service) band (1700/2100 MHz band) in Auction 66 to $\$ 1.28 / \mathrm{MHz} / \mathrm{Pop}$ for the $700 \mathrm{MHz}$ band in Auction 73. At these prices, aggregating a significant regional spectrum footprint would involve an outlay of hundreds of millions of dollars and a national footprint would require billions of dollars. 223

The prices of these spectrum licenses are driven up because of the scarcity of the available spectrum. If spectrum were more readily available or even tradable by the parties, one would expect the prices of spectrum to decrease. Again the FCC is citing an example of a barrier to entry that it created. The 14th and 15th Wireless Reports also note that carriers have increasingly relied on mergers and acquisitions to mitigate spectrum shortages. ${ }^{224}$ Once again, this activity is driven by a lack of access to necessary resources.

Skeptics might argue that releasing additional spectrum is difficult because there is simply not much spectrum left to be released. There is spectrum to be had, however, if the FCC reclaims spectrum that is unused, which would undo its poor allocation in the first place. For example, the following spectrum could be repurposed: (1) the broadcasters' spectrum, (2) AWS-3 spectrum, (3) $400 \mathrm{MHz}$ of spectrum identified by the World Radio Conference, and (4) $555 \mathrm{MHz}$ of spectrum designated as unlicensed U-NII spectrum for use in wireless broadband. ${ }^{225}$ This spectrum could provide the necessary spectrum to at least temporarily meet the surging demand for wireless applications.

Another potential solution would be to eliminate the spectrum allocation currently used by the FCC, which has resulted in spectrum misallocation and underutilization and, instead, treat spectrum as a more standard commodity (together with technical restrictions in spectrum licenses to protect against interference). In this scenario, spectrum would be like real estate: it could be bought, sold, leased, aggregated, or divided up as the market dictates. This solution is in line with the standard approach to a public good problem in economics known as the "Coase

223. Id. at para. 62 .

224. Id. at para. 75; 15th Wireless Report, supra note 4, at para. 75.

225. For a more lengthy discussion of these issues see Faulhaber \& Farber, supra note 206, at 94-96. 
Theorem. ${ }^{226}$ This Coasian solution allows for spectrum to be put to its highest valued use, and it also allows for demand to be met in a more timely fashion as opposed to the bureaucracy-riddled method currently used by regulators. ${ }^{227}$ Although such a method is likely to have its share of detractors and political pitfalls, it is by far a more efficient solution to the spectrum crisis.

\section{CONCLUSION}

Our analysis suggests that the U.S. wireless services industry is effectively competitively supplied, just as the FCC concluded in its six prior competition reports through the 13th iteration. Although the industry did become more concentrated between the FCC's 13th and 14th Wireless Reports, there is no economic rationale for changing a finding of effective competition based on that evidence alone. Indeed, there does not appear to be a clear statistical relationship between market structure and what customers pay in the wireless industry based on recent data. The absence of such a relationship is presumably due to the dynamic nature of the industry and the degree to which competition occurs along multiple dimensions, including handset and network quality. In drafting its next report, the FCC should bring its mode of analysis in line with modern economic thinking. Unless it can demonstrate a direct linkage between concentration and performance in today's mobile wireless market, it should deemphasize the importance it attaches to market structure.

226. The Coase Theorem asserts that when property rights are involved, parties naturally gravitate toward the most efficient and mutually beneficial outcome.

227. See, e.g., Gerald Faulhaber, The Question of Spectrum: Technology, Management and Regime Change, 4 J. ON TELECOMM. \& High TeCH. L. 123 (2005). 
Appendix 1: Wireless Plans Available in Washington, D.C. for Less Than \$40 Per Month

\begin{tabular}{|c|c|c|c|}
\hline \multicolumn{4}{|c|}{ PRICE POINT } \\
\hline MINUTES & $\$ 29.99$ & $\$ 35.00$ & $\$ 39.99$ \\
\hline Unlimited & & $\begin{array}{c}\text { Leap } \\
\text { (Voice }+ \text { Text) } \\
\text { Sprint } \\
\text { (After } 18 \text { months) }\end{array}$ & $\begin{array}{c}\text { Sprint } \\
\text { (After } 12 \text { months) }\end{array}$ \\
\hline 1500 & $\begin{array}{c}\text { T-Mobile } \\
\text { (Monthly Pre- } \\
\text { paid, Data) }\end{array}$ & & \\
\hline 500 & & & $\begin{array}{l}\text { T-Mobile } \\
\text { (Voice) }\end{array}$ \\
\hline 450 & & & $\begin{array}{l}\text { Verizon } \\
\text { (Voice) } \\
\text { AT\&T } \\
\text { (Voice) } \\
\text { Sprint } \\
\text { (Voice) }\end{array}$ \\
\hline 200 & $\begin{array}{c}\text { Sprint } \\
\text { (Voice) } \\
\text { AT\&T } \\
\text { (65+ only) }\end{array}$ & & \\
\hline
\end{tabular}




\section{Appendix 2A: Alternative Regression Specifications}

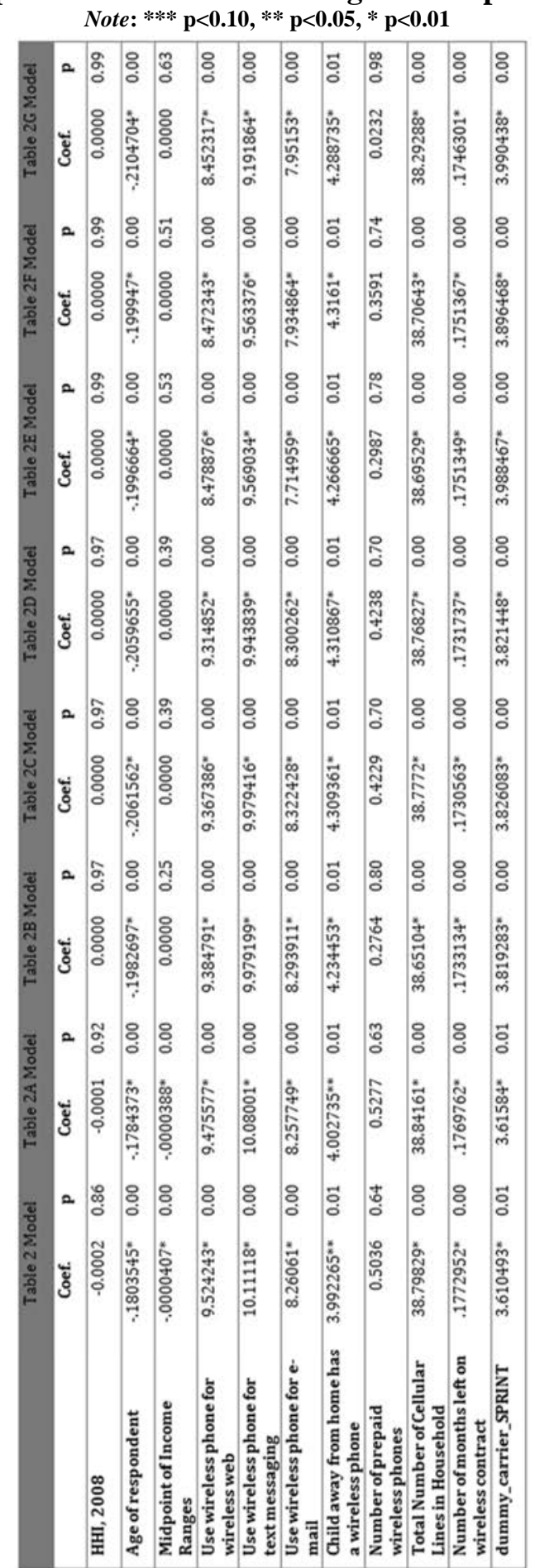




\section{Appendix 2B: Alternative Regression Specifications}

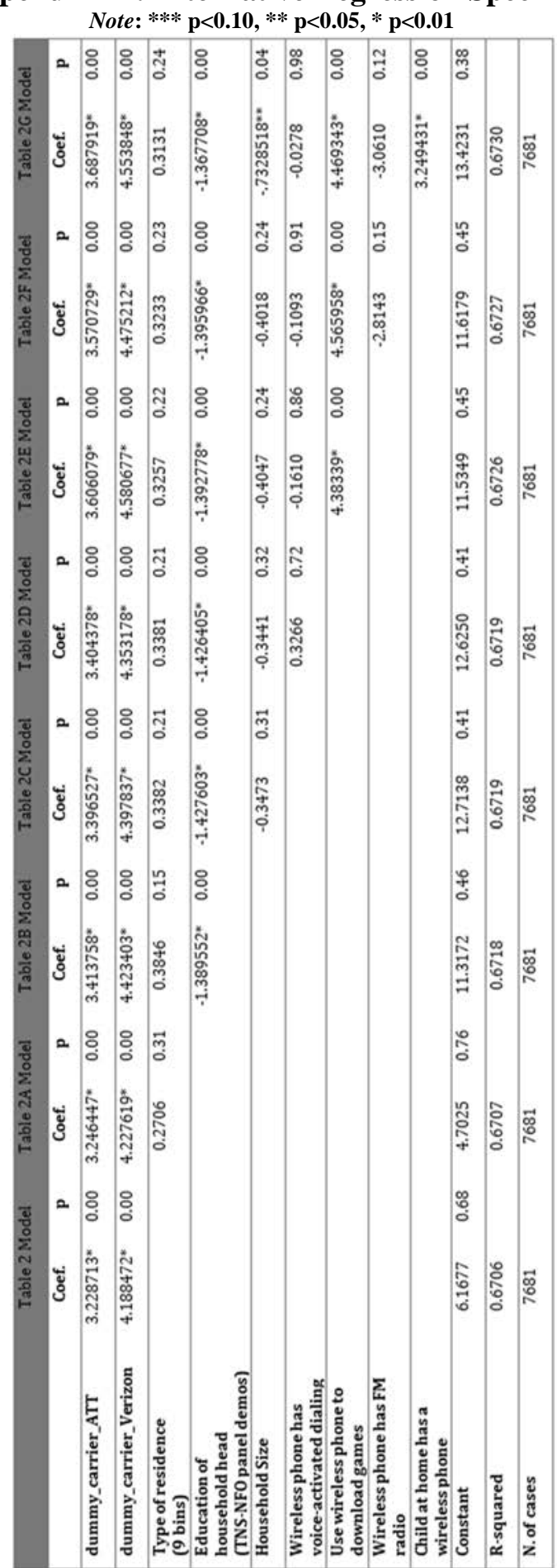


